\title{
ELECTRICITY UNIT VALUE PRICES AND PURCHASE QUANTITIES: U.S. MANUFACTURING PLANTS, 1963-2000
}

\author{
Steven J. Davis, Cheryl Grim, John Haltiwanger, and Mary Streitwieser*
}

\begin{abstract}
We measure unit value electricity prices using 2 million annual observations on U.S. manufacturing plants from 1963 to 2000. These prices display tremendous cross-sectional dispersion, $85-95 \%$ of which reflects differences by plant location and purchase quantity. Spatial differentials decline markedly until the late 1980s for large purchasers but rise over time for small purchasers. Unit value price gaps between larger and smaller purchasers are enormous, diminish through the late 1970s, and then stabilize at still-high levels. There are major differences across states in cost and regulatory factors that we relate to the changing structure of unit value prices.
\end{abstract}

\section{Introduction}

$\mathrm{L}$ ONGSTANDING concerns and recent developments have combined to intensify interest in the performance of the U.S. electric power industry. These include persistent regional disparities in retail prices, growth in wholesale power markets, a wave of restructuring and deregulation initiatives in the 1990s, difficulties in the transition to a more competitive electricity sector, and, perhaps most spectacular, the California electricity crisis of 2000-2001. ${ }^{1}$ Despite these concerns and developments, there are few broad empirical studies of electricity prices paid by end users and major gaps in our knowledge of retail pricing patterns and their evolution over time. These gaps hamper efforts to place recent developments in historical perspective and evaluate the impact of regulatory changes on the structure of electricity prices that end users pay.

To help address these issues, we construct a rich micro database-Prices and Quantities of Electricity in Manufacturing (PQEM) - and use it to study the electricity pricing

Received for publication June 1, 2010. Revision accepted for publication May 16, 2012.

* Davis: University of Chicago, NBER, and American Enterprise Institute; Grim: Bureau of the Census; Haltiwanger: University of Maryland, Bureau of the Census, and NBER; Streitwieser: Bureau of Economic Analysis.

We thank Wayne Gray, Eddie Lazear, Catherine Wolfram, an anonymous referee, and seminar and conference participants at the Berkeley Energy Group, Center for Economic Studies at the Census Bureau, London School of Economics, Penn State, Tokyo University, University of Chicago, University of Toronto, the July 2004 NBER Conference on Research in Income and Wealth, the 2005 Western Economic Association International Conference, and the January 2009 North American Meetings of the Econometric Society for many helpful comments. We thank Monica Garcia-Perez, Alan Finkelstein Shapiro, and Brock Williams for excellent research assistance. We are especially grateful to Rodney Dunn for comments and assistance with the EIA-861 data files. S. D. and J. H. gratefully acknowledge research support from the U.S. National Science Foundation under grant number SBR9730667. S. D. also acknowledges research support from the Stigler Center for the Study of the Economy and the State at the University of Chicago. Any opinions and conclusions expressed here are those of the authors and do not necessarily represent the views of the U.S. Census Bureau, the Bureau of Economic Analysis, or the U.S. Department of Commerce. All results have been reviewed to ensure that no confidential information is disclosed.

A supplemental appendix is available online at http://www.mitpress journals.org/doi/suppl/10.1162/REST_a_00309.

${ }^{1}$ Hirsh (1999), U.S. Energy Information Administration (2000b), Besanko et al. (2001), Borenstein (2002), and Joskow (2005), among others, describe and analyze these matters. to U.S. manufacturing plants from 1963 to 2000. The PQEM includes data on electricity expenditures, purchases (watt-hours), and other variables for more than 48,000 manufacturing plants per year. We link these customer-level data to additional data on the utilities that supply electricity. Our customer-level data are limited to manufacturers, but they are informative about pricing practices for a broader class of customers that includes other industrial customers and large and midsize commercial customers. ${ }^{2}$

Our measures of electricity prices and quantities have advantages and limitations. The main advantage is comprehensive coverage of plant-level prices and quantities for a representative panel of manufacturing plants over a fortyyear period. The plant-level data permit us to investigate the structure and distribution of prices and quantities across plants and time. For example, we analyze the structure of prices and quantities across industrial customers within and between utilities over a forty-year period in an unprecedented manner. The main limitation is that our plant-level price measure is the annual unit value price-the ratio of annual expenditures on purchased electricity to annual purchase quantity. Many prominent studies of electricity prices use similar unit value prices (Joskow, 1974, 2000, 2006; Besley \& Coate, 2003). ${ }^{3}$ Like those studies, we must be cautious in our interpretation, because we do not measure marginal electricity prices at specific moments in time (for example, by time of day) or the detailed structure of electricity tariff schedules. Keeping this limitation in mind, in what follows we use "price" as shorthand for the annual unit value price and "quantity" for the annual purchase quantity.

Figure 1 displays several measures of dispersion in the distribution of $\log$ electricity prices from 1963 to $2000 .^{4}$

\footnotetext{
${ }^{2}$ We inspected electricity tariffs for several utilities and found that they offered the same menu of pricing terms to manufacturers, other industrial customers, and large and midsize commercial customers. In addition, average electricity prices behave similarly for the manufacturing sector and the industrial sector as a whole, as we show below. Industrial purchasers account for $45 \%$ of retail electricity sales (watt-hours) in 1963 and $31 \%$ in 2000 (EIA, 2003a). Manufacturing accounts for the lion's share of electricity purchases by the industrial sector.

${ }^{3}$ For example, Joskow (2006, tables 7 and 8) and Besley and Coate (2003, table 2) consider panel regressions of state-by-year electricity "prices" on a variety of factors, with the dependent variable price measured as the ratio of annual expenditures to annual $\mathrm{kWh}$. Our advantage relative to their measures is that we can construct analogous measures at the plant level.

${ }_{4}^{4}$ The natural $\log$ transformation is convenient for characterizing the magnitude of price dispersion. In addition, electricity transmission over power lines and the process of transforming voltage levels involve costs in the form of electrical energy dissipated as heat energy. The dissipation of electrical energy rises with transmission distance, other things equal, so that price differences across locations (hereafter spatial price differentials) are aptly described in log terms. For these reasons, we often consider log price differentials in this paper, but we also consider prices measured in natural units.
} 
Figure 1.-Electricity Price Dispersion across U.S. Manufacturing Plants, 1963-2000

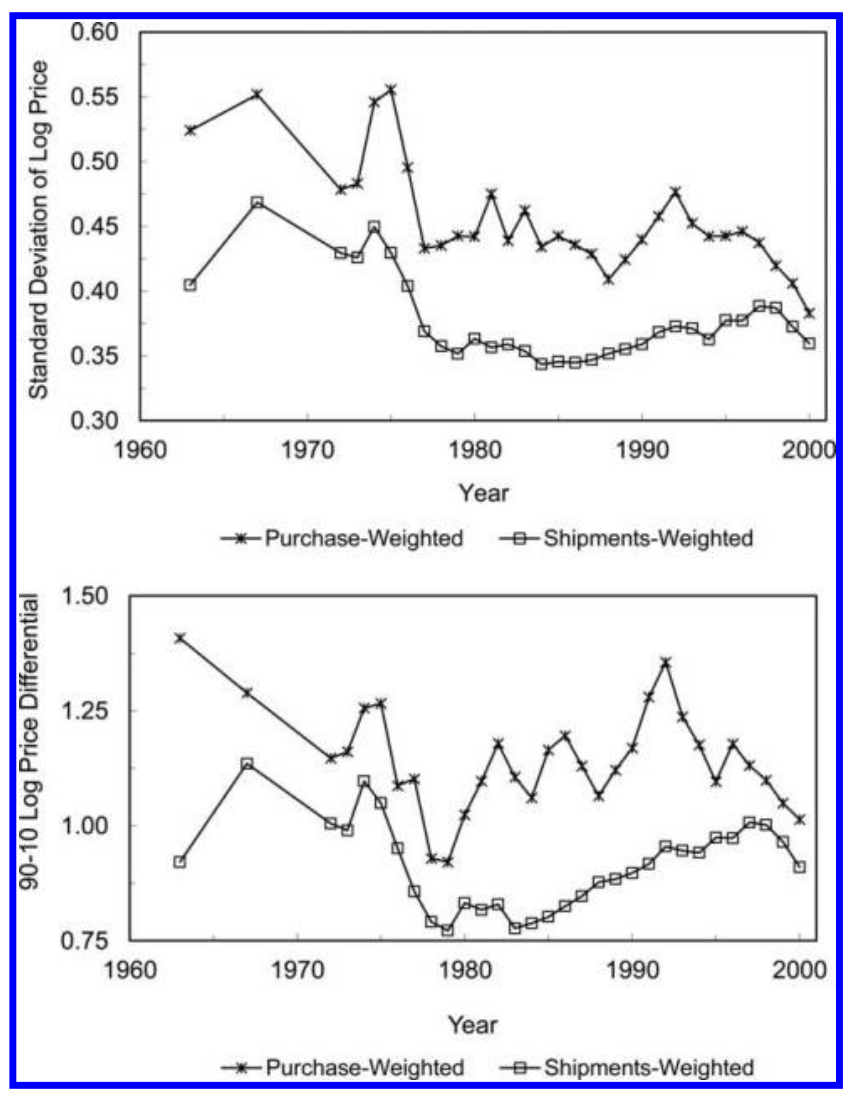

Source: Authors' calculations on PQEM data.

The figure shows purchase-weighted and shipmentsweighted price distributions, where the former weights each customer-level observation by watt-hours of electricity purchases and the latter weights by shipments. ${ }^{5}$ The figure shows a tremendous dispersion in the price per kilowatthour $(\mathrm{kWh})$ paid by manufacturing plants. The purchaseweighted standard deviation exceeds $38 \mathrm{log}$ points in all years and reaches $55 \log$ points in some years. By way of comparison, the hours-weighted standard deviation of log hourly production worker wages among manufacturing plants in the PQEM ranges from 39 to $43 \mathrm{log}$ points between 1975 and $1993 .^{6}$ In other words, the dispersion in electricity prices among manufacturing plants is at least as great as the dispersion in their average hourly wages. ${ }^{7}$

Figure 1 also reveals that the log price distribution underwent a large compression from 1967 to the late 1970s. The

\footnotetext{
${ }^{5}$ These weighting methods mirror the use of input-weighted and output-weighted distributions in plant-level studies of productivity growth. Examples include Foster, Haltiwanger, and Krizan (2001) and Van Biesebroeck (2004).

${ }^{6}$ The PQEM lacks clean measures of hourly wages before 1975 or after 1993. See Davis and Haltiwanger (1991) for a detailed study of betweenplant wage dispersion in the U.S. manufacturing sector.

${ }^{7}$ We note that the literature on wages also often relies heavily on unit value wage measures constructed as the ratio of annual earnings to annual hours worked.
}

between-plant standard deviation fell from $55 \log$ points in 1967 to $44 \log$ points in 1979 on a purchase-weighted basis and from 47 to $35 \log$ points on a shipments-weighted basis. Over the same time frame, the 90-10 price differential shrank by about $37 \log$ points under both weighting methods. The 90-10 differential later widened but never returned to the peaks of the 1960s. To the best of our knowledge, we are the first to quantify the remarkable extent of electricity price dispersion for a major end user group and the first to document the price compression that played out by the late 1970s.

We show that this compression episode reflects shrinking price gaps between larger and smaller purchasers. These gaps reflect a variety of factors, including the tariff rate structure within utilities, customer responses to pricing incentives, and spatial variation in the location of large and small producers. On a purchase-weighted basis, the crosssectional average elasticity of price with respect to annual purchase quantity shrank from $-22 \%$ in 1967 to about $-9 \%$ in the late 1970 s, partially recovering after the mid1980s. Because the range of electricity purchases among manufacturers is enormous, these elasticities translate into very large price gaps. For example, prices for the biggest purchasers were two-thirds below the median price in the 1960s. Plant-level differences in purchase amounts account for $75 \%$ of overall price dispersion among manufacturers in 1963 but only $30 \%$ by 1978 .

One of the factors potentially at work in the flattening of the price-quantity relationship is the changing structure of tariffs within utilities. Historically, utilities used decliningblock tariff structures, so that the largest purchasers paid lower prices. There were substantial regulatory reforms in the U.S. electric power industry during our sample period. At the national level, the 1978 Public Utilities Regulatory Policies Act (PURPA) included a variety of measures designed to encourage energy conservation, including a shift away from declining block tariffs. As Joskow emphasizes in several important studies (1979a, 1979b), regulatory reforms did not proceed at an even pace across states. Partly motivated by this observation, we exploit cross-state differences in the pace of regulatory reform to estimate the effect of regulatory factors in determining the slope of the price-quantity relationship and driving its flattening over time. In this regard, we also consider the role of state-level electricity cost factors.

We also develop new evidence on spatial price differentials across counties and utility service territories. First, spatial price dispersion in the top decile of the purchases distribution fell sharply from the 1960s to the late 1980s. This finding suggests that retail power markets became more geographically integrated for the largest electricity users. Second, and in sharp contrast, spatial price differentials widened over time in the lower deciles of the purchases distribution. Third, in the 1990s, when wholesale power markets grew rapidly, spatial price dispersion at the retail level did not diminish and even rose modestly over much of the purchases distribution. 
The next section provides a background discussion of the changing nature of the electric industry over the past few decades. Section III describes the PQEM database. Section IV quantifies the dispersion of electricity prices between and within industries, counties, utilities, and purchase size classes. Section V discusses cost and demand influences on electricity pricing and develops evidence on the electricity price-quantity relationship and its evolution over time. Section VI investigates the cross-state differences in the changing structure of prices and quantities and the role of crossstate differences in the pace of regulatory reform (among other factors) in accounting for the these changes. The concluding section summarizes our main findings.

\section{The Changing Nature of the Electric Utility Industry}

From its inception in the 1880s until the mid-1960s, the electric power industry enjoyed a golden era characterized by rapid improvements in generating technology, plentiful capacity, and declining electricity prices. ${ }^{8}$ Utilities offered promotional block pricing whereby the price per $\mathrm{kWh}$ declined with purchase amounts. Stimulated by falling real prices, declining block pricing, and new electrical appliances and machinery, electricity consumption grew rapidly after World War II (Hirsh, 1989).

During this period, electric utilities were able to increase profits and at the same time decrease prices (Joskow, 2000). Thus, state public utility commissions, which were responsible for setting prices, had little need for lengthy, formal rate-of-return hearings generally required only for price increases. ${ }^{9}$ This golden era drew to a close by the late 1960s as unforeseen technological and metallurgical barriers hampered progress in the creation of better electric generators. ${ }^{10}$

Economic factors in the late 1960s and 1970s exacerbated the technological problems facing the industry. Inflation and nominal interest rates began to rise in the late 1960 s, causing a drop in utility rates of return. By the early 1970s, most utilities needed to raise prices, setting off a cascade of rate-of-return hearings (Joskow, 1974, 1979b). Adding to the problem, prices then rose sharply for coal and oil,

\footnotetext{
${ }^{8}$ This view, widely shared by knowledgeable observers, is articulated at length in Hirsh (1999). Joskow (1989) puts it this way: "During the 1950s and most of the 1960s the electric power industry attracted little attention from public policy makers. It experienced high productivity growth, falling nominal and real prices, excellent financial performance, and little regulatory or political controversy."

${ }^{9}$ State public utility commissions were responsible for setting prices and approving major electric industry infrastructure investments. In theory, state commissions set prices such that the average revenue per unit sold is equal to the average cost of supplying the unit (Joskow \& Schmalensee, 1986). Note that the Federal Energy Regulatory Commission (FERC) had limited power in terms of prices; it could regulate wholesale power transactions and interstate transmission service provided to a third party. For more detailed discussion of the regulatory process, see Joskow and Schmalensee (1986) and Joskow $(1989,2000)$.

${ }^{10}$ Chapters 7 and 8 in Hirsh (1989) provide a detailed discussion of the technological difficulties that confronted the electric power industry in the late 1960 s and the 1970 s.
}

major fuel sources for electricity generation, and there were big disruptions in petroleum supplies. The OPEC oil embargo of 1973 precipitated a dramatic rise in oil prices, as did the Iranian revolution of 1979.

Several regulatory developments added to cost pressures and tightened capacity constraints. Concerns about pollution from conventional power plants and about safety at nuclear power plants led to several pieces of legislation in the late 1960s and 1970s (one was the Clean Air Act of 1970) that raised costs and hampered the operation and development of the industry. ${ }^{11}$ Environmental concerns also found their way into rate-of-return hearings (Joskow, 1974). Environmentalists criticized the price structure of the electric industry for being designed to encourage growth in demand.

Together, the events of the late 1960s and early 1970s created a favorable environment for rate reform. Several states made early moves toward some form of peak-load pricing. As of 1976, twelve states had held generic rate hearings where marginal cost pricing was discussed in detail, ten states had federally funded rate experiments to determine the effects of alternative rate structures on consumer behavior, and sixteen had actual time-of-day rates filed by electric utilities (Joskow, 1979b). States implementing time-of-day rates included California, New York, and Wisconsin. $^{12}$ These initial time-of-day rates were available almost exclusively to large industrial customers.

In 1978, several major pieces of legislation passed as part of President Carter's National Energy Plan. The plan included the gradual removal of price controls on oil and natural gas, restrictions on the use of oil and natural gas by generating plants, and rate reform provisions for electric utilities. The Public Utilities Regulatory Policies Act (PURPA) of 1978 had the biggest impact on the electricity sector. ${ }^{13}$ Its rate reform provisions were hotly contested in Congress (Joskow, 1979a; Hirsh, 1999), but in their final form, they required that state regulatory authorities merely

\footnotetext{
${ }^{11}$ The National Environmental Policy Act of 1969 required utilities to prepare and defend environmental impact statements for new generator sites. The Clean Air Act of 1970 restricted air pollutants at electricitygenerating plants and encouraged utilities to switch from coal to cleaner burning oil or natural gas. The Federal Water Pollution Control Act of 1972 limited waste discharge, and the Resource Conservation and Recovery Act of 1976 set forth standards for utility waste products. Following the 1973 energy crisis, the Energy Supply and Environmental Coordination Act of 1974 authorized the federal government to prohibit purchases of natural gas and petroleum by utilities. (Legislation after the energy crisis was intended to reduce U.S. dependency on other countries for fuel. Some of this legislation was in direct opposition to earlier legislation intended to increase environmental cleanliness.) The Clean Air Act Amendments of 1977 imposed more stringent restrictions on emissions from electricity-generating plants. See appendix A of U.S. Energy Information Administration (2000b) for a detailed description of legislation summarized in this paragraph.

${ }^{12}$ Other states with time-of-day rates on file by 1976 were Connecticut, Delaware, Florida, Georgia, Illinois, Iowa, Michigan, Minnesota, New Hampshire, North Carolina, Pennsylvania, Vermont, and Virginia. See Joskow (1979b).

${ }^{13}$ See Joskow (1989), White (1996), and Hirsh (1999). Hirsh (1999) and Gordon (1982) provide extensive discussion of PURPA.
} 
Figure 2.-Real Electricity Prices by End Use Sector, 1960-2000

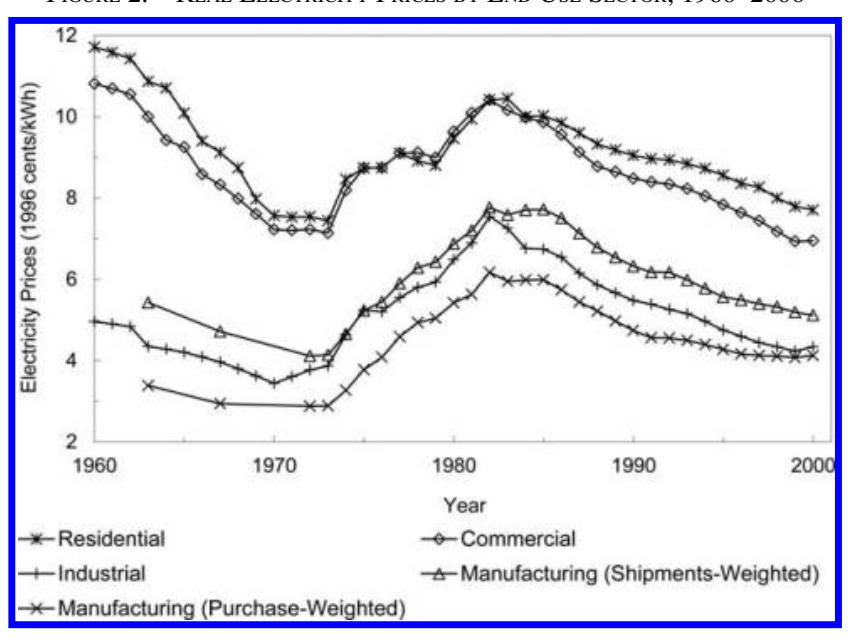

Source: U.S. Energy Information Administration for Residential, Commercial and Industrial series authors' calculations on PQEM data for manufacturing.

consider various reforms that included an end to promotional pricing. Title II of PURPA required utilities to buy from and sell power to qualifying facilities (QFs). The goal was to draw nonutilities, such as cogeneration plants and renewable resource plants, into the electric power market. States had different responses to Title II, with some states requiring utilities to sign long-term contracts (twenty to thirty years) with QFs at what turned out to be very high prices (Joskow, 2000). Title II of PURPA was effective. By 1999 , nonutilities owned nearly $20 \%$ of the electric generating capacity in the United States (U.S. Energy Information Administration, 2000a).

The effect of these technological, economic and regulatory developments on retail electricity prices can be seen in figure 2, which plots the average real price per $\mathrm{kWh}$ for major end user sectors. ${ }^{14}$ Real electricity prices ceased falling in 1970 and began to rise after 1973, partly because of sharply higher costs for the fossil fuels that powered many of the generating plants. Real electricity prices continued to rise for about ten years before resuming the historical pattern of steady declines.

Wholesale trade in electric power expanded rapidly in the 1990s, stimulated by legislative and regulatory policy changes. The Energy Policy Act of 1992 (EPACT) sought to promote greater competition and participation in wholesale markets and unbundle the sale of electric power from transmission and distribution services (White, 1996; Besanko, D'Souza, \& Thiagarajan, 2001). Title II of

\footnotetext{
${ }^{14}$ The electricity price series in figure 2 for the residential, commercial, and industrial sectors are from the U.S Energy Information Administration (EIA), and the two series for the manufacturing sector are constructed from the PQEM. The EIA data rely on reports from electric utilities, and the PQEM data rely on reports from electricity customers (manufacturing plants). EIA prices are calculated as revenue from retail electricity sales divided by $\mathrm{kWh}$ delivered to retail customers. Real prices are calculated using the BEA implicit price deflator for GDP $(1996=100)$. In the EIA data, the industrial sector encompasses manufacturing, mining, construction, and agriculture.
}

PURPA, FERC Orders 888 and 889 (issued in 1996), and various state-level actions during the 1990s also stimulated growth in wholesale power markets. These legislative and regulatory actions helped to create a new class of power producers (nonutility qualifying facilities) with secure access to transmission facilities and exemption from many restrictions on public utilities. Sales of electricity for resale rose from $41 \%$ of generated power in 1991 to $61 \%$ in 2000 (U.S. Energy Information Administration, 2003b).

Starting in the late 1990s, several states undertook efforts, not always successful, to introduce greater retail competition in the electricity sector. According to Joskow (2005), the "first retail competition programs began operating in Massachusetts, Rhode Island and California in early 1998 and spread to about a dozen states by the end of 2000." These developments on the retail side occur at the end of the period covered by our data.

\section{The PQEM Database}

The PQEM database derives principally from the U.S. Census Bureau's Annual Survey of Manufactures (ASM) and various files produced by the U.S. Energy Information Administration (EIA). We draw our data on electricity prices and quantities and other variables for individual manufacturing plants from ASM microfiles for 1963, 1967, and 1972-2000. The ASM is a series of nationally representative, five-year panels refreshed by births as a panel ages. Large manufacturing plants with at least 250 employees are sampled with certainty, and smaller plants with at least 5 employees are sampled randomly with probabilities that increase with the number of employees. ${ }^{15}$ ASM plants account for about one-sixth of all manufacturing plants and about three-quarters of manufacturing employment. Our statistics make use of ASM sample weights, so our results are nationally representative.

ASM plants report expenditures for purchased electricity during the calendar year and annual purchases (in $\mathrm{kWh}$ ). We calculate the plant-level unit value price ("price" for short) as annual expenditures on purchased electricity divided by annual purchase quantity. The ASM includes street address and county and state codes, which are helpful in assigning manufacturing plants to electricity suppliers. As we describe at length in Davis et al. (2007), we identified and resolved several issues with ASM electricity price and quantity measures in the course of preparing this study. We also checked the ASM data against the Manufacturing Energy Consumption Survey, another plant-level data source at the U.S. Census Bureau that relies on a different survey.

\footnotetext{
15 The number of employees required to be a certainty case is lower in 1963 and 1967. In 1963, all plants in a multi-plant firm with 100 or more employees were sampled with certainty. The same was true in 1967 except for plants in apparel (SIC 23) and printing and publishing (SIC 27), which had certainty thresholds of 250 employees. In 1999, the employment criterion for certainty cases was raised from 250 to 500 employees.
} 
Table 1.-Selected Characteristics of the PQEM Database

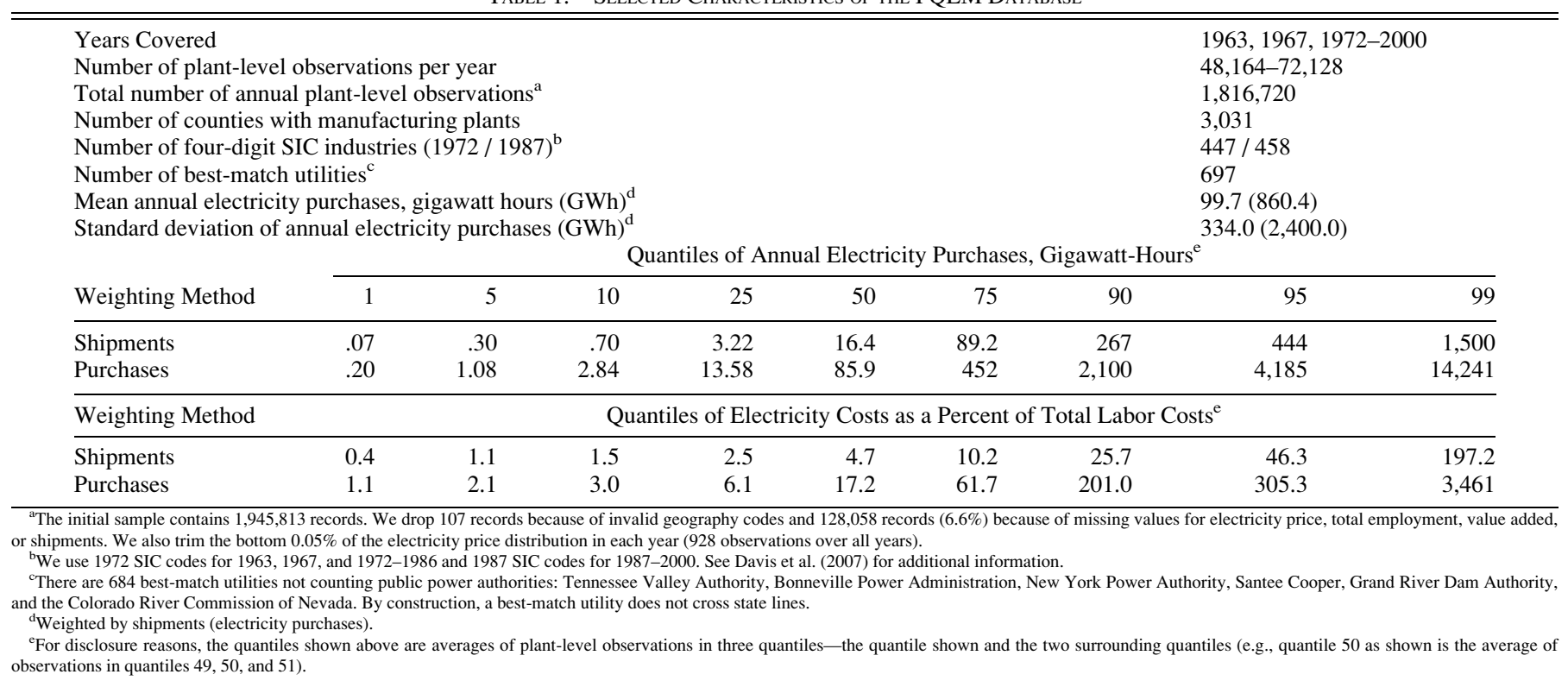

We linked ASM plants to their electricity suppliers using several sources of information. The Annual Electric Utility Reports, also known as the EIA-861 files, include each utility's revenue from sales to industrial customers (by state) and a list of the counties in which the utility has industrial customers. These files provide an immediate match to the utility for plants in counties served by a single utility. For many states, we are able to supplement the EIA-861 files with geographic information system (GIS) maps, a list of postal codes served by each utility, or printed maps showing utility service territories. These supplemental sources of information enable us to construct accurate matches for counties served by more than one utility. We have supplemental geographic information for eighteen states, accounting for $49 \%$ of electricity purchases and $54 \%$ of manufacturing shipments. For plants in states without this type of information, we created a "best-match" utility indicator using the method described in the online appendix.

We also exploit publicly available information on the identity of plants that purchase electricity directly from the six largest public power authorities. ${ }^{16}$ Direct purchasers from public power authorities typically consume large quantities of electricity, and they often accept high-voltage power, operate their own transformers, and obtain electric power at heavily discounted rates. While few in number, these direct purchasers account for a large fraction of electricity purchases in some counties, and they constitute a distinct segment of the retail electricity market. We identified

\footnotetext{
16 They are the Tennessee Valley Authority, Bonneville Power Administration, Santee Cooper, New York Power Authority, Grand River Dam Authority, and Colorado River Commission of Nevada. Fourteen public power authorities supplied electricity directly to industrial customers in 2000 , but the six largest accounted for nearly $98 \%$ of the revenues from direct sales to industrial customers (EIA-861 file).
}

between 56 and 93 direct purchasers from public power authorities per year.

Finally, we incorporated the State Energy Data 2008 files into the PQEM. ${ }^{17}$ These files contain annual data on fuel sources used for electricity generation by state from 1960 to 2008. We construct annual state-level fuel shares in electric power generation for five categories: coal, petroleum and natural gas, hydropower, nuclear power, and other (includes geothermal, wind, wood and waste, photovoltaic, and solar).

Table 1 reports selected characteristics of the PQEM. The database contains more than 1.8 million plant-level observations from 1963 to 2000 . There are 3,031 counties with manufacturing plants and 697 utilities, counting multistate utilities once for each state in which they sell to industrial customers. The table shows that electricity purchases and cost shares vary enormously across manufacturing plants. For example, the 90th quantile of the purchases distribution is 381 times the 10th quantile on a shipments-weighted basis and 739 times on a purchase-weighted basis. The median ratio of electricity costs to labor costs is $4.7 \%$ on a shipments-weighted basis and $17.2 \%$ on a purchase-weighted basis. While electricity costs are a modest percentage of labor costs for most plants, they exceed $62 \%$ of labor costs in the top quartile and $200 \%$ of labor costs in the top decile.

\section{Electricity Price Dispersion}

After trending down for nearly a century, real electricity prices began to rise after 1973 and then continued to rise for about ten years, before resuming the historical pattern

\footnotetext{
${ }^{17}$ These data are from the State Energy Data System on the EIA Internet site, www.eia.doe.gov.
} 
Table 2.-Distribution of Log Electricity Prices Paid by U.S. Manufacturing Plants, Dispersion and Variance Decompositions

\begin{tabular}{|c|c|c|c|c|c|c|c|c|c|}
\hline & 1963 & 1967 & 1972 & 1977 & 1982 & 1987 & 1992 & 1997 & 2000 \\
\hline \multicolumn{10}{|c|}{ Overall standard Deviation } \\
\hline Shipments weighted & .409 & .468 & .429 & .369 & .359 & .347 & .373 & .388 & .360 \\
\hline Purchase weighted & .524 & .552 & .478 & .433 & .439 & .429 & .477 & .437 & .383 \\
\hline \multicolumn{10}{|c|}{ Price Dispersion between Groups as a Percent of the Total } \\
\hline \multicolumn{10}{|c|}{ 4-digit SIC industries $(447 / 458)^{\mathrm{a}}$} \\
\hline Shipments weighted & 36.6 & 36.3 & 28.0 & 20.6 & 19.4 & 23.1 & 26.4 & 25.1 & 23.8 \\
\hline Purchase weighted & 71.3 & 61.4 & 48.8 & 40.9 & 37.9 & 46.8 & 59.0 & 44.5 & 37.5 \\
\hline \multicolumn{10}{|l|}{ Utilities (697) } \\
\hline Shipments weighted & 20.4 & 22.1 & 23.5 & 44.3 & 58.3 & 45.7 & 52.9 & 48.9 & 47.3 \\
\hline Purchase weighted & 67.2 & 58.4 & 52.3 & 60.0 & 65.2 & 56.8 & 59.1 & 55.0 & 52.7 \\
\hline \multicolumn{10}{|l|}{ Counties $(3,031)$} \\
\hline Shipments weighted & 31.4 & 32.0 & 32.2 & 53.0 & 67.2 & 54.3 & 61.6 & 57.6 & 56.3 \\
\hline Purchase weighted & 77.9 & 69.6 & 64.9 & 73.5 & 78.6 & 74.9 & 77.5 & 69.9 & 65.4 \\
\hline \multicolumn{10}{|l|}{ Purchase deciles (10) } \\
\hline Shipments weighted & 57.2 & 54.2 & 33.2 & 16.4 & 19.3 & 26.2 & 29.0 & 30.6 & 25.6 \\
\hline Purchase weighted & 62.8 & 56.3 & 36.2 & 27.4 & 24.7 & 38.0 & 49.5 & 41.3 & 38.1 \\
\hline \multicolumn{10}{|l|}{ Purchase centiles $(100)^{\mathrm{b}}$} \\
\hline Shipments weighted & 61.1 & 57.2 & 35.8 & 18.6 & 21.6 & 28.7 & 31.9 & 32.7 & 29.0 \\
\hline Purchase weighted & 74.7 & 65.5 & 41.5 & 33.8 & 31.8 & 45.0 & 60.8 & 45.9 & 43.4 \\
\hline \multicolumn{10}{|c|}{ Utility $\times$ Purchase Centile $(32,142)$} \\
\hline Shipments weighted & 84.1 & 79.6 & 67.7 & 71.5 & 83.1 & 78.5 & 85.1 & 83.8 & 81.9 \\
\hline Purchase weighted & 94.7 & 91.1 & 81.6 & 84.5 & 88.4 & 88.3 & 91.7 & 87.5 & 86.3 \\
\hline
\end{tabular}

of steady declines. Figure 2 shows that these broad trends hold for all major end user groups. We discussed the market, technological, regulatory, and other factors behind these broad trends in section II. Here, we focus on price dispersion (again measured using annual unit value prices) among manufacturing customers.

To decompose the cross-sectional variance of log electricity prices into within-group and between-group components (for example, industry, region), write the overall variance as

$$
\begin{aligned}
& V=\sum_{e} s_{e}\left(p_{e}-\bar{p}\right)^{2}=\sum_{g} \sum_{e \in g} s_{e}\left(p_{e}-\bar{p}\right)^{2}, \\
& V=\sum_{g} s_{g}\left(\sum_{e \in g} s_{e}\left(p_{e}-\bar{p}_{g}\right)^{2}\right)+\sum_{g} s_{g}\left(\bar{p}_{g}-\bar{p}\right)^{2}, \\
& V=\sum_{g} s_{g} V_{g}^{W}+V^{B}=V^{W}+V^{B},
\end{aligned}
$$

where $p_{e}$ is the $\log$ price for plant $e, s_{e}$ is the weight, $\bar{p}$ is the overall weighted mean $\log$ price, $\bar{p}_{g}$ is the weighted mean $\log$ price for group $g, s_{g}=\sum_{e \in g} s_{e}$ is the sum of weights for plants in group $g, V_{g}^{W}$ is the weighted variance within $g$, and $V^{B}$ is the between-group variance. Table 2 reports shipments-weighted and purchase-weighted versions of equation (1) for selected years, with $s_{e}$ set to the product of the plant's ASM sample weight and its shipments or purchases value. The unit of observation in this decomposition is an electricity customer, that is, a manufacturing plant. Weighting by shipments (purchases) yields information about price dispersion across units of customer output (customer input).

According to table 2, the shipments-weighted standard deviation of $\log$ electricity prices across manufacturing plants stood at $47 \log$ points in 1967, fell sharply to $37 \mathrm{log}$ points by 1977 , and then changed little over the next 23 years. Price dispersion also fell sharply on a purchaseweighted basis, from $55 \log$ points in 1967 to $43 \mathrm{log}$ points in 1977 and then further in the 1990s to stand at $38 \mathrm{log}$ points in 2000. Following a similar path, the between-industry dispersion of electricity prices fell rapidly through 1982 and to even lower levels in the 1990s on a purchase-weighted basis. All told, the purchase-weighted dispersion of industry prices fell by almost half over the past four decades.

Table 2 also documents other noteworthy facts. First, spatial price differentials are large. County effects, for example, never account for less than $65 \%$ of the overall price variance on a purchase-weighted basis. Second, customer groups defined by electricity purchase quantities also account for a high percentage of overall price dispersion, especially in the 1960s. Price dispersion across purchase centiles fell by nearly half during our sample period, mostly between 1967 and 1977. Third, purchase level and utility jointly account for a high percentage of price dispersion throughout the past four decades. Groups defined by utility crossed with purchase centile account for $85 \%-95 \%$ of the purchase-weighted variance.

Trends in spatial price dispersion show a complex pattern. For example, the purchase-weighted between-county standard deviation fell by nearly one-third from 1963 to 2000, while the analogous shipments-weighted measure rose by one-fifth. Closer examination reveals that spatial dispersion fell in the top decile of the purchases distribution (more heavily weighted in purchase-weighted analyses), but it rose in the lowest deciles (more heavily weighted in shipments-weighted analyses). We highlight this pattern in figure 3, which shows the evolution of spatial price dispersion for three selected deciles. To control for purchase quantity within deciles, figure 3 uses residuals from annual 
Figure 3.-Spatial Price Dispersion by Selected Deciles of the Purchases Distribution, 1963-2000

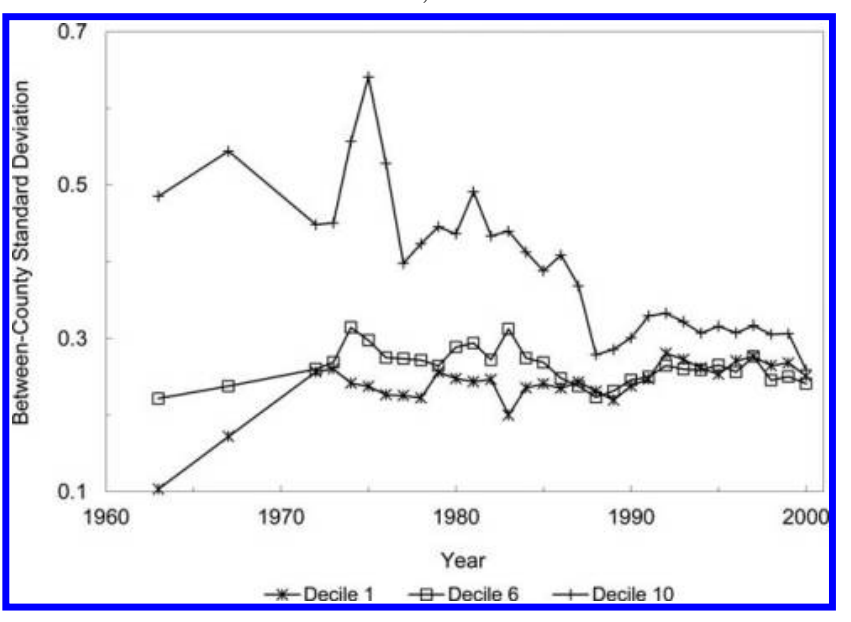

The between-county standard deviations are calculated in a purchase-weighted manner using residual from annual customer-level regressions of log price on a fifth-order polynomial in log purchases.

Source: Authors' calculations on PQEM data.

customer-level regressions of log price on a fifth-order polynomial in log purchases. As seen in figure 3, there is an enormous decline from the late 1960 s to the late 1980 s in spatial dispersion within decile 10 (comprising the biggest purchasers). A similar but more muted pattern holds for decile 9. The middle deciles exhibit little trend change in spatial dispersion, as illustrated by decile 6 . The lower deciles exhibit trend increases in spatial dispersion, as illustrated by decile 1 . Another noteworthy pattern highlighted by figure 3 is the lack of a downward trend in spatial price dispersion during the 1990s, when wholesale power markets grew rapidly. Sales of electricity for resale rose from $41 \%$ of generated power in 1991 to $61 \%$ in 2000 (U.S. Energy Information Administration, 2003b).

We summarize the empirical findings to this point in three statements: (a) there is tremendous dispersion across manufacturing plants in price paid per $\mathrm{kWh},(\mathrm{b})$ the plantlevel distribution of electricity prices underwent a large compression through the late 1970s, and (c) readily observed customer characteristics-purchase quantity and location, or utility-capture $85 \%$ to $95 \%$ of the cross-sectional price variation. The rest of this paper more fully explores the role of utility characteristics and customer purchase quantity in the structure of electricity prices for manufacturing plants.

\section{The Electricity Price-Quantity Relationship}

\section{A. Cost and Demand Influences on the Electricity Price- Quantity Relationship}

Supply costs per kWh of electricity tend to be lower for larger industrial and commercial customers for several reasons. Large purchasers are more likely to locate near generating facilities to minimize transmission losses. Highvoltage transmission lines can lead all the way to the custo- mer's doorstep, reducing transmission costs further. A large power user is also more likely to operate equipment at high voltage levels, circumventing or reducing the need for stepdown transformers and complex distribution networks. Large power users may operate and maintain their own step-down transformers as well, relieving the utility of this task and associated costs. Larger electricity customers also have stronger incentives to respond to pricing structures that discourage volatile consumption patterns and peakperiod consumption. In turn, these incentive responses economize on generating and transmission facilities and mute the effect of system-wide demand fluctuations on generating costs. Similarly, larger customers have stronger incentives to consider provisions for interruptible and curtailable power as a means of lowering electricity costs. These customer supply characteristics provide a cost basis for lower prices for larger purchasers.

Customer demand characteristics also lead to prices falling with purchased quantity under plausible conditions. Ramsey pricing logic suggests that a utility should price at a smaller markup over the cost of supply for more pricesensitive customers. If demand is more price elastic for manufacturing plants that use more electric power, then the Ramsey logic translates into prices that decline with customer purchase quantity. Of course, customer supply costs and customer demand characteristics can contribute to the price-quantity relationship at the same time.

\section{B. Electricity Tariffs for Industrial Customers}

Electricity tariffs for industrial customers usually include separate energy and "demand" charges. ${ }^{18}$ The energy charge depends on total kilowatt-hours of consumption during the billing period, and the demand charge depends on the highest consumption over fifteen- or thirty-minute intervals within the billing period or longer time period. The demand charge roughly reflects the customer's maximal requirements for power. By discouraging uneven and erratic patterns of power consumption, the separate demand charge economizes on the need for generating, transmission, and transformer facilities. Eligibility for the most favorable tariff schedules is usually limited to large customers that make long-term commitments to minimum contract demand levels that place a high floor on monthly charges.

Traditionally, electric utilities offered declining-block rate schedules, whereby the marginal price per $\mathrm{kWh}$ of energy and the marginal price per $\mathrm{kW}$ of demand decline as step functions (Caywood, 1972). For bigger purchasers in particular, electricity tariffs also depend on other factors, such as voltage level and willingness to accept power interruptions or curtailments. Differential rates by time of day and other applications of peak-load pricing principles came

\footnotetext{
${ }^{18}$ See Cowern (2001) for a concise introduction to electricity tariffs for industrial customers. Caywood (1972) provides a detailed description of electricity tariffs and rate-setting practices.
} 
Table 3.-Menu of Electricity Tariff Schedules Offered to Industrial Customers by Santee Cooper Power as of July 2004

\begin{tabular}{|c|c|c|c|c|c|c|}
\hline $\begin{array}{l}\text { Service Type } \\
\text { and Schedule }\end{array}$ & $\begin{array}{l}\text { Energy } \\
\text { Charge per } \\
\mathrm{kWh}\end{array}$ & $\begin{array}{l}\text { Monthly Demand } \\
\text { Charge per kW }\end{array}$ & $\begin{array}{l}\text { Minimum } \\
\text { Monthly } \\
\text { Demand } \\
\text { Charge }\end{array}$ & $\begin{array}{l}\text { Own } \\
\text { Transformer } \\
\text { Discount? }\end{array}$ & $\begin{array}{l}\text { Monthly } \\
\text { Customer } \\
\text { Charge }\end{array}$ & Customer Profile \\
\hline General Service, GN-96 & $6.56 \varnothing$ & None & None & No & $\$ 6.85$ & Less than $90 \mathrm{MWh}$ per year \\
\hline $\begin{array}{l}\text { Medium General Service, } \\
\text { GS-96 }\end{array}$ & $2.60 \varnothing$ & $\$ 11.85$ & $\$ 11.85$ & No & $\$ 16.15$ & $\begin{array}{l}\text { Greater than } 90 \mathrm{MWh} \text { and less } \\
\text { than } 1,080 \mathrm{MWh} \text { per year }\end{array}$ \\
\hline $\begin{array}{l}\text { Large General Service, } \\
\text { GL-96 (optional provision } \\
\text { for interruptible power) }\end{array}$ & $2.32 \varnothing$ & $\begin{array}{l}\$ 13.20(\$ 8.57 \text { for } \\
\text { interruptible } \\
\text { portion })\end{array}$ & $\$ 3,960$ & $\begin{array}{l}\text { Yes; } \$ 0.50 \\
\text { per } \mathrm{kW}\end{array}$ & $\$ 24.00$ & $\begin{array}{l}\text { Greater than } 1,080 \text { MWh per } \\
\text { year and delivery points } \\
\text { near transmission line }\end{array}$ \\
\hline $\begin{array}{l}\text { General Service Time of Use, } \\
\text { GT-96 }\end{array}$ & $2.32 \varnothing$ & $\begin{array}{l}\$ 13.20 \text { peak, } \$ 3.87 \\
\text { off-peak }\end{array}$ & & No & $\$ 24.00$ & $\begin{array}{l}\text { Greater than } 90 \mathrm{MWh} \\
\text { per year }\end{array}$ \\
\hline $\begin{array}{l}\text { Large Power and Light, L-96 } \\
\text { (requires 5-year contract } \\
\text { with high floor on demand } \\
\text { charges) }\end{array}$ & $2.19 \varnothing$ & $\begin{array}{l}\$ 10.76 \text { (extra } \$ 6.00 \\
\text { per } \mathrm{kW} \text { in excess of } \\
\text { contract level) }\end{array}$ & $\begin{array}{l}\$ 10,760 \text { (for } \\
1,000 \mathrm{~kW} \\
\text { of Firm } \\
\text { Power) }\end{array}$ & $\begin{array}{l}\text { Yes; } \$ 0.50 \\
\text { per } k W\end{array}$ & $\$ 1,200$ & $\begin{array}{l}\text { Demand greater than } 1,000 \\
\mathrm{~kW} \text { and delivery points } \\
\text { near transmission lines; } \\
\text { minimum five-year } \\
\text { commitment. }\end{array}$ \\
\hline
\end{tabular}

Curtailable Supplemental
Power, L-97

Interruptible Power, L-02-I

Off-Peak Service, L-96-OP

Economy Power, L-02-EP

Standby Power, L-96-SB
Different energy charges and a discount of $72 \%$ on demand charges for supplemental power subject to temporary or permanent curtailment or interruption with six months' notice.

Discount of $36 \%$ on demand charges for power subject to curtailment or interruption on short notice (2.5 hours); limitations on frequency and duration of curtailments and interruptions; one-year advance notice required by customer to reduce interruptible portion of demand.

Discount of $80 \%$ on demand charges for off-peak power in excess of contracted levels for firm, supplemental, and interruptible demands; subject to curtailment or interruption on short notice.

Discounted energy charges offered, at Santee Cooper's sole discretion, to customers with contract demand greater than $2,000 \mathrm{~kW}$; available on short notice during specified clock hours.

Available at Santee Cooper's discretion to customers with alternative nonemergency power sources.

The charges listed above exclude South Carolina sales tax and other taxes and fees levied by governmental authorities.

Electricity is metered and billed separately for each delivery point and voltage level, so that the monthly customer charge and minimum monthly demand charge apply per delivery point and voltage level.

All service types are subject to a fuel adjustment clause (FAC-96) whereby the energy charge per kWh is adjusted by an additive factor that depends on Santee Cooper's fuel costs in the preceding three months, an allowance for its capital improvements and distribution losses, and other considerations. The energy charge adjustment per kWh is similar for all service types, but the adjustment is less sensitive to capital improvements and distribution losses under the Large Power and Light schedule. Under all schedules, standard firm requirements service is also subject to a demand sales adjustment Clause (DSC-96) that credits Santee Cooper customers with specified shares of its demand-related and capacity-related revenues. The adjustment can be positive or negative. It is applied as a proportional adjustment to the monthly demand charge under the Large Power and Light schedule and as a proportional adjustment to the monthly energy charge under the General Service schedules.

The $\mathrm{kW}$ level used to calculate the monthly demand charge can be greater than measured demand during the billing period, defined as "the maximum 30-minute integrated $\mathrm{kW}$ demand recorded by suitable measuring device during each billing period." For example, the medium general service schedule states that the "monthly Billing Demand shall be the greater of (i) the Measured Demand for the current billing period or (ii) fifty percent $(50 \%)$ of the greatest Firm Billing Demand computed for the preceding eleven months." The large general service schedule specifies a $70 \%$ figure.

The discounted demand charge under the general service time-of-use schedule applies to the difference between the customer's off-peak measured demand and the customer's on-peak measured demand.

The transformer discount requires that the customer take delivery at available transmission voltage ( $69 \mathrm{kV}$ or greater).

Customers who opt for curtailable or interruptible power forfeit all discounts previously received during the calendar year for such power in the event they fail to meet a request for power curtailment or interrupCustomers who opt for curtailable or interruptible power forfeit all discounts previously
tion. In addition, future discounts for curtailable and interruptible power can be withdrawn.

tion. In addition, future discounts for curtailable and interruptible power can be withdrawn.
Under the Large Power and Light schedule, the customer must commit to a firm contract demand level for a five-year period. The firm contract level places a floor on the demand level used to compute the monthly Under the Large Power and Light schedule, the customer must commit to a firm contract demand level for a five-year period. The firm contract level places a floor on the demand level used to compute the monthly
demand charge. Lower minimum monthly demand charges are available under certain conditions. The Large Light and Power Schedule also includes an excess demand charge of $\$ 6.00$ per kW for Measured Demand in excess of the firm contract demand, a charge of $\$ 0.44$ per kVAr of excess reactive demand, and a monthly facilitie Charge equal to $1.4 \%$ of the original installed cost of any facilities that Santee Cooper provides in addition to the facilities it normally provides to its customers.

Source: Santee Cooper tariff schedules for commercial and industrial customers at http://www.santeecooper.com/ (July 20, 2004).

into wider use after the mid-1970s (Environmental Law Reporter, 1975; Cudahy \& Malko, 1976; Joskow, 1979b). Moves toward more finely differentiated tariff schedules for industrial customers continued through the late 1980s (Wilson, 1993). The California electricity crisis of 20002001 intensified interest in retail pricing structures and their reform (Borenstein, 2002).

To illustrate the type of pricing structure that prevailed in our sample period, table 3 summarizes the menu of electricity tariff schedules offered to industrial customers by Santee Cooper Power. ${ }^{19}$ There are three main charges: a monthly customer charge, monthly demand charges, and monthly energy charges. Larger customers face smaller

\footnotetext{
${ }^{19}$ Santee Cooper is also known as the South Carolina Public Service Authority. Among utilities with positive industrial revenue, Santee Cooper is close to average size, with industrial sales of $\$ 238$ million in 2000. The Santee Cooper schedules reflected in table 3 were in effect as of July 2004 and date back to 1996. Schedules downloaded from http://www .santeecooper.com/ on July 20, 2004.
}

energy charges per $\mathrm{kWh}$ and smaller demand charges per $\mathrm{kW}$ but higher monthly minimum charges. For example, the Medium General Service schedule offers an energy charge of $2.6 \notin$ per $\mathrm{kWh}$, a demand charge of $\$ 11.85$ per $\mathrm{kW}$, and a minimum monthly payment of $\$ 29$. The Large Power and Light schedule offers a lower energy charge of $2.19 \notin$ per $\mathrm{kWh}$ and a lower demand charge of $\$ 10.76$ per $\mathrm{kW}$ but a much higher minimum monthly payment of $\$ 11,960 .{ }^{20}$ Large Santee Cooper customers that locate near transmission lines and provide their own transformers receive discounts of roughly $4 \%$ on demand charges. Optional riders to the Large Power and Light schedule offer big discounts on demand charges for off-peak power and power subject to curtailment or interruption. The Large Power and Light schedule and its optional riders require a

\footnotetext{
${ }^{20}$ This monthly minimum holds for a customer contracting for at least $1,000 \mathrm{~kW}$ of firm power. Lower minimum charges are available to customers that accept interruptible or curtailable power.
} 
Figure 4.- - Log Electricity Price Fit to Fifth-Order Polynomials in Log Purchases, Selected Years

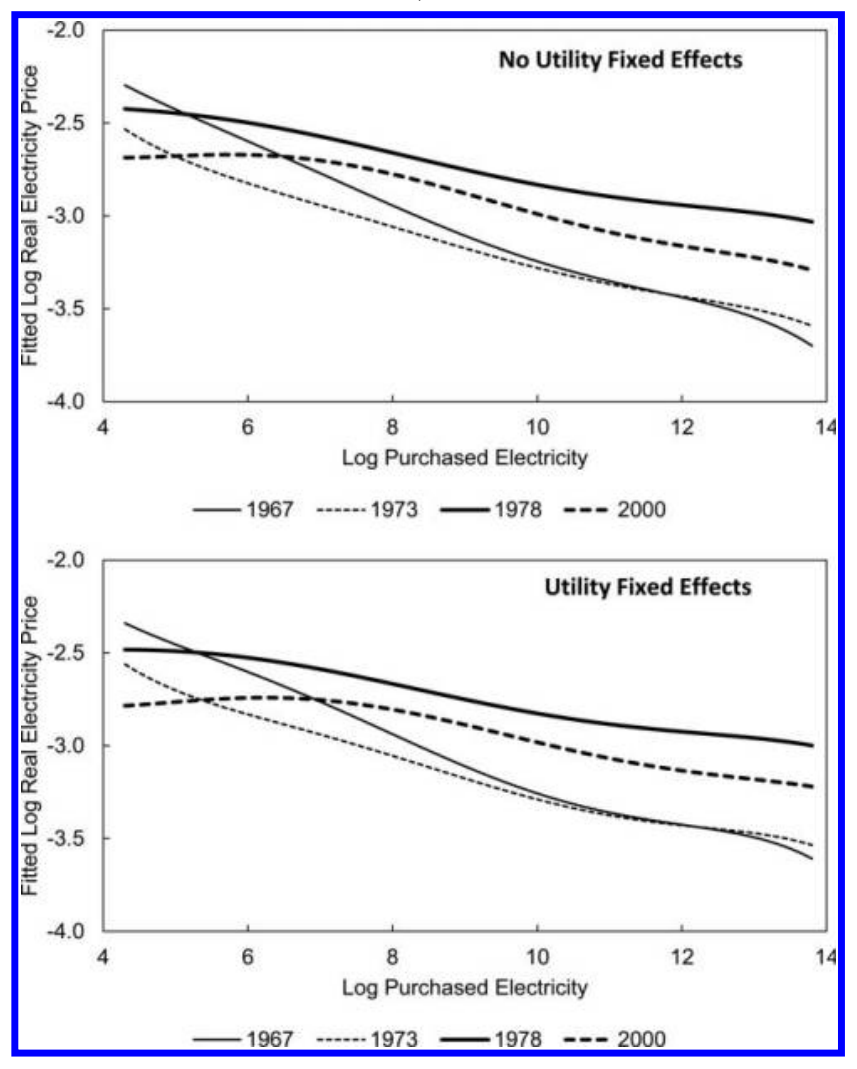

Each curve depicts the fitted regression from the 1st to 99th percentiles of the shipments-weighted distribution of customer-level purchase quantities. Curves are fit separately by year to the customer-leve data. For reference, simple means of the 5 th, 25 th, 50 th, 75 th, and 95 th percentiles of the purchase distributions over 1967, 1973, 1978, and 2000 are 5.5, 7.8, 9.5, 11.2, and 12.9. The lower panel controls for utility fixed effects; the upper panel does not.

Source: Authors' calculations on PQEM data.

five-year customer commitment to a contract demand level of at least $1,000 \mathrm{~kW}$ and the implied demand charges. These basic features of the Santee Cooper tariff schedules are similar to the tariff menu offered to industrial customers by Pacific Gas \& Electric in 1988 (Wilson, 1993) and to the illustrative tariff schedule for industrial customers in Electric Utility Rate Economics (Caywood, 1956, 1972).

The PQEM does not capture the full complexity of the underlying electricity tariff schedules. Consistent with the literature (Joskow, 1974, 2000, 2006; Besley \& Coate, 2003), we recognize that this measure of the unit value price has limitations but should still reflect many of the factors influencing a more direct measure of the marginal price. In this respect, the PQEM is analogous to individual and establishment-level data sets that report earnings and hours worked but not the details of underlying compensation arrangements. To be sure, the lack of data on the underlying tariff schedules (or compensation terms) is a limitation, but it does not preclude an informative analysis. Despite the complexity of compensation arrangements, a vast body of informative research on labor costs and the wage structure fruitfully exploits relatively simple data on wage rates for individual workers and employers. Our empirical analysis and much previous work on electricity pricing proceed in the same spirit.

\section{Empirical Price-Quantity Schedules}

We now present evidence on empirical price-quantity schedules for electric power. When a plant operates for only part of the calendar year, the PQEM measure of kWh purchases does not accurately indicate where the plant fits into the purchases distribution. For this reason, we henceforth exclude part-year observations. We also exclude observations that display extreme seasonality or within-year variation in production activity. ${ }^{21}$ Customers with highly variable loads typically face special tariff schedules with higher charges. ${ }^{22}$

The top panel of figure 4 displays empirical price-quantity schedules for selected years. Each curve shows the fit from a customer-level regression of $\log$ price on a fifthorder polynomial in the log of annual purchases. ${ }^{23}$ We run the regressions separately by year, weighting each observation by its shipments value and ASM sample weight. The results show a dramatic flattening of the price-quantity schedule between 1967 and 1978. The fitted price differential between the 25th and 75th quantiles of the purchase distribution shrinks from $46 \log$ points in 1967 to $26 \log$ points in 1978, and the gap between the 5th and 95th quantiles shrinks from 103 to $51 \log$ points. ${ }^{24}$ In short, there was a remarkable flattening of the relationship between price and quantity between 1967 and the late 1970s.

For comparison, the bottom panel of figure 4 shows price-quantity schedules fitted exclusively from within-utility variation. Except for the inclusion of utility fixed effects, the specification underlying the bottom panel of figure 4 is identical to the specification underlying the top panel. It is apparent that even after controlling for utility fixed effects, prices decline with purchase quantity in all years, and there is a substantial flattening of the price-quantity relationship in the 1970s.

\footnotetext{
${ }^{21}$ Specifically, we exclude observations for which the number of production workers in any single quarter is less than $5 \%$ of the annual average number of production workers. These observations represent less than $2 \%$ of shipments and electricity purchases in each year.

${ }^{22}$ For example, Santee Cooper tariff schedule TP for temporary service (such as ballpark lighting) specifies a flat rate of $7.23 \phi$ per $\mathrm{kWh}$. Schedule GV for seasonal general service specifies energy charges of $2.34 \phi$ per $\mathrm{kWh}$ and demand charges of $\$ 14.35$ per $\mathrm{kW}$.

${ }^{23}$ We also considered nonparametric regression fits for the price-quantity schedule using the SAS GAM procedure (spline option, 100 degrees of freedom). Except at the extreme upper end of the purchase distribution, accounting for less than $1 \%$ of shipments, the nonparametric fits are highly similar to the fifth-order polynomial fits. Given this similarity and the much longer run times for the nonparametric fits, especially when we add covariates, we focus on polynomial fits throughout the paper. See figure W1 in the online appendix for a nonparametric description of how price per $\mathrm{kWh}$ varies with purchase quantity and how the price-quantity relationship evolves over time.

${ }^{24}$ We also created analogs to figure 4 for the five utilities with the largest number of customer-level observations (several hundred per year).
} All five utilities show the same basic pattern as in figure 4 . 
Figure 5.-Average Elasticity of Price with Respect to Purchase Quantity, $1963-2000$

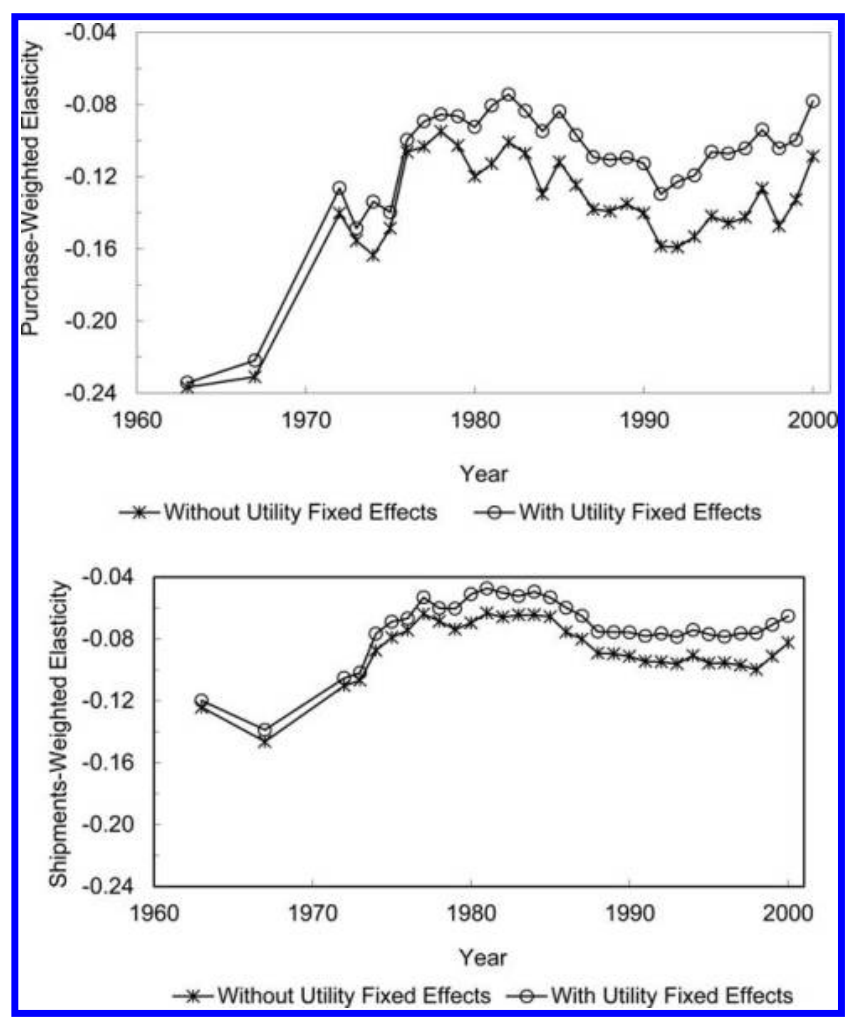

Elasticity values are calculated from shipments-weighted regressions of the log price on a fifth-order polynomial in log annual purchases using customer-level data.

polynomial in log annual purchases using custom
Source: Authors' calculations on PQEM data.

We carried out analogous regressions for each year in the PQEM data. To summarize the results, we compute the average empirical elasticity of price with respect to purchase quantity by year. Figure 5 plots these average elasticities and confirms a dramatic flattening of price-quantity schedules through the late 1970s. In the 1960s, the average price-quantity elasticity is $-22 \%$ on a purchase-weighted basis, and it ranges from $-12 \%$ to $-14 \%$ on a shipmentsweighted basis. The magnitude of the price-quantity elasticity falls by more than half by 1980 .

The inclusion of utility fixed effects has a modest impact on the average elasticity values, especially prior to 1974. This result implies that the purchase-level price differentials in figure 4 overwhelmingly reflect within-utility price differences. Nevertheless, figure 5 clearly shows that betweenutility price differences contribute to the overall negative relationship between price per $\mathrm{kWh}$ and customer purchase quantity. One possible interpretation is that larger users of power are more likely to locate where power is relatively cheap. In line with this interpretation, the bigger role of utility fixed effects after 1973 (see figure 5) suggests that the rising cost of power (see figure 2) encouraged a migration of electricity-intensive manufacturing activity to areas served by utilities with cheaper electricity. Still, most of the flattening in the price-quantity relationship is within utilities, so such spatial allocation plays only a supporting role.
In summary, we emphasize that the two main patterns in figure 4 are robust to controlling for utility fixed effects. First, utilities charge much less per $\mathrm{kWh}$ to customers that purchase more power during the year. Second, there was a substantial flattening of the price-quantity relationship within utilities.

\section{Behavioral Responses by Customers and Built-in Discounts in the Tariff Schedules}

The empirical price-quantity schedule reflects a variety of factors, including the tariff schedules and customer behavioral responses to pricing incentives. Bigger purchasers have greater opportunity and incentive to reduce the price paid per kWh by managing load factors (ratio of average to peak demand), taking high-voltage power, responding to peak-load pricing incentives, and accepting curtailable or interruptible power. These behavioral responses affect the observed relationship between price per $\mathrm{kWh}$ and purchase quantity. We now provide suggestive evidence that these behavioral responses are an important factor in the negative relationship between price per $\mathrm{kWh}$ and annual purchase quantity within utilities, as documented in figures 4 and 5 .

Specifically, we compare the price-quantity schedule for firm power implied by the Santee Cooper tariff menu to the empirical price-quantity schedule. In tracing out the implied Santee Cooper schedule, we fix the customer load factor at $50 \%$ and exclude discounts for off-peak or high-voltage power. ${ }^{25}$ In this way, we foreclose reductions in price with quantity purchased that arise from behavioral responses and isolate the price-quantity relationship built into the tariff structure. We then compare the price-quantity schedule implied by the menu of tariff schedules offered by Santee Cooper to the fitted price-quantity schedule for manufacturing plants in the 2000 PQEM. Note that the empirical pricequantity schedule fit to the PQEM captures both the built-in size effect and any behavioral responses by electricity customers.

Figure 6 plots the implied Santee Cooper price-quantity schedule alongside the fitted price-quantity schedule for 2000 from the lower panel of figure $4 .^{26}$ Figure 6 suggests that both built-in and behavioral sources of reductions in price with quantity are important features of the data. Over the middle part of the distribution that roughly spans the interquartile range of purchases by manufacturing plants, the price per kWh implied by the Santee Cooper tariff menu declines with purchase quantity by 30 to $40 \log$ points. That

\footnotetext{
25 Specifically, we compute the lower envelope of the price-quantity schedules implied by the General Service, Medium General Service, Large General Service, and Large Power and Light schedules. Recall that the tariff schedules described in table 3 do not include taxes or adjustments specified by the fuel adjustment clause and the demand sales adjustment clause. Santee Cooper is a utility for which it is relatively straightforward to compute this lower envelope given the relatively small number of different tariff schedules.

${ }^{26}$ We do not have enough observations on Santee Cooper customers to fit an empirical price-quantity schedule for Santee Cooper alone.
} 
Figure 6.-Comparison of the Price-Quantity Schedule Implied by the Santee Cooper Tariff Schedules to the Empirical Price-Quantity SCHEDULE IN 2000

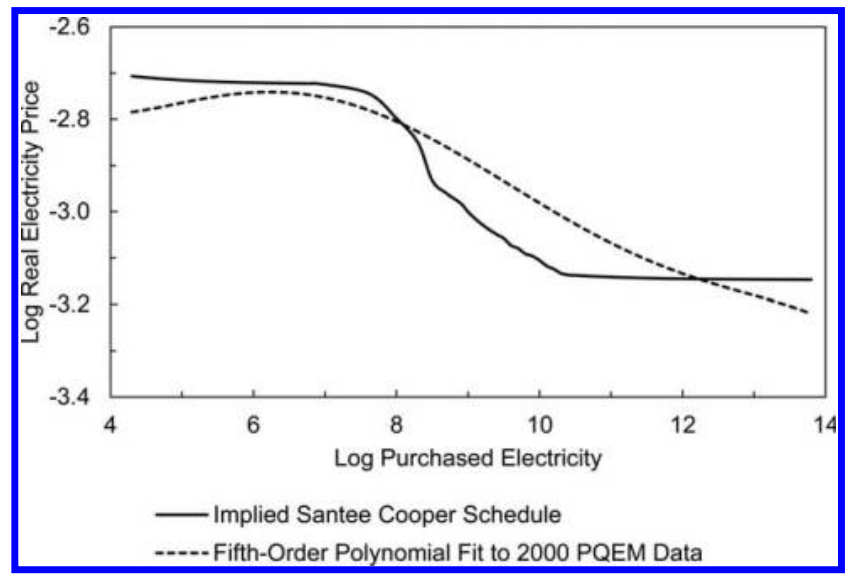

The regression fit on the PQEM data controls for utility fixed effects. For reference, simple means of the 5th, 25th, 50th, 75th, and 95th percentiles of the purchase distributions over 1967, 1973, 1978, and 2000 are $5.5,7.8,9.5,11.2$, and 12.9 .

Source: Authors' calculations on PQEM data and Santee Cooper tariff schedules.

is, over this range, large reductions in price with purchase quantity are built into the Santee Cooper menu of tariff schedules. ${ }^{27}$ In contrast, figure 6 suggests that reductions in price with purchased quantity in the upper quartile of the distribution reflect behavioral responses to pricing incentives. This aspect of the figure points to a nontrivial price elasticity for large purchasers.

Although behavioral responses can account for some of the observed price-quantity relationship, figure 6 also implies that the price-quantity structure reflects the declining block structure of tariffs at Santee Cooper even in 2000. As discussed in section II, there has been substantial regulatory reform in the electric utility industry over the past forty years. In the next section, we investigate the role of this regulatory reform by relating cross-state differences in the changes in the price-quantity relationship to cross-state variation in the pace of this regulatory reform.

\section{The Role of Regulatory and Cost Factors}

The dramatic flattening of the price-quantity schedule in the 1970s occurred during a time, as noted in section II, that many related changes were occurring in the electricity industry. It was a time of rapidly rising oil prices that had a large impact on utility supply costs and a time of high inflation. The rising fuel costs and inflation put pressures on utility commissions to raise rates, which typically required hearings. The rising prices led to increasing concerns by the public and policymakers about the efficiency of electric utilities. This was also a time of increased attention to the impact of energy use on the environment. The greater pre-

\footnotetext{
${ }^{27}$ The implied schedule declines more rapidly than the empirical schedule over this range, which suggests that the Santee Cooper tariff menu involves bigger built-in reductions in price with respect to quantity than the average utility.
}

valence of hearings provided a setting for all of these concerns to become part of the public debate. All of these factors were associated with changes in energy policy in the United States at the national and state levels.

At the aggregate level, it is difficult to sort out the different factors influencing the flattening price-quantity relationships depicted in figure 5. However, by considering variation across states in the price-quantity relationships over time, we can potentially identify how these different factors played a role. Moreover, the cross-state differences are interesting in their own right, and it may be that only a small number of states account for the patterns in figure 5 . So we now explore the patterns and determinants of variation in the state-by-year elasticities of prices with respect to purchase quantities. Our objective is to quantify the nature of the differences across states and identify determinants of the differences across states and over time. To begin, we repeat the figure 5 exercise for each state, while controlling for utility fixed effects to capture the price-quantity relationship within utilities.

Figure 7 summarizes the differences across states in the changes in the elasticity of prices with respect to purchased electricity. The top panels of figure 7 exploit differences in the 1967-1982 changes across states. That is, we rank states in terms of their 1967-1982 changes in elasticities on both a purchase- and shipments-weighted basis. On a purchaseweighted basis, the top quartile of states experiences a very large change in the elasticity-more than $30 \mathrm{log}$ points between 1967 and 1982. In contrast, the bottom quartile of states experienced only modest changes in the elasticity from 1967 to 1982 . On a shipments-weighted basis, we find only modest differences between the top and bottom quartiles. In other words, there is not much heterogeneity across states in the 1967-1982 changes in the shipments-weighted elasticity.

In the bottom panels of figure 7 , we rank states by an index of electricity intensity in manufacturing production activity. We construct this index as follows. First, we use the PQEM data to measure electricity cost shares by industry at the national level by year. Second, we compute each industry's share of shipments at the state-year level. Finally, we compute the index by weighting the national industrylevel electricity cost shares with the state-level industry shipments shares. The online appendix describes the index construction in more detail and provides evidence on how it differs across states and over time.

The bottom left panel in figure 7 shows that states with an electricity-intensive industry structure in 1967 had much steeper price-quantity schedules in the early part of our sample period. It also shows that the average purchaseweighted elasticity in these states largely converged to the average elasticity in states with index values in the bottom quartile by 1980 . States in the top quartile experienced about a $20 \log$ point change in the elasticity from 1967 to 1982, while states in the bottom quartile experienced only about a 5 log point change in the elasticity. Thus, much of 
Figure 7.-Elasticity of Price with Respect to Purchase Quantity, 1963-2000, Selected Groupings of States

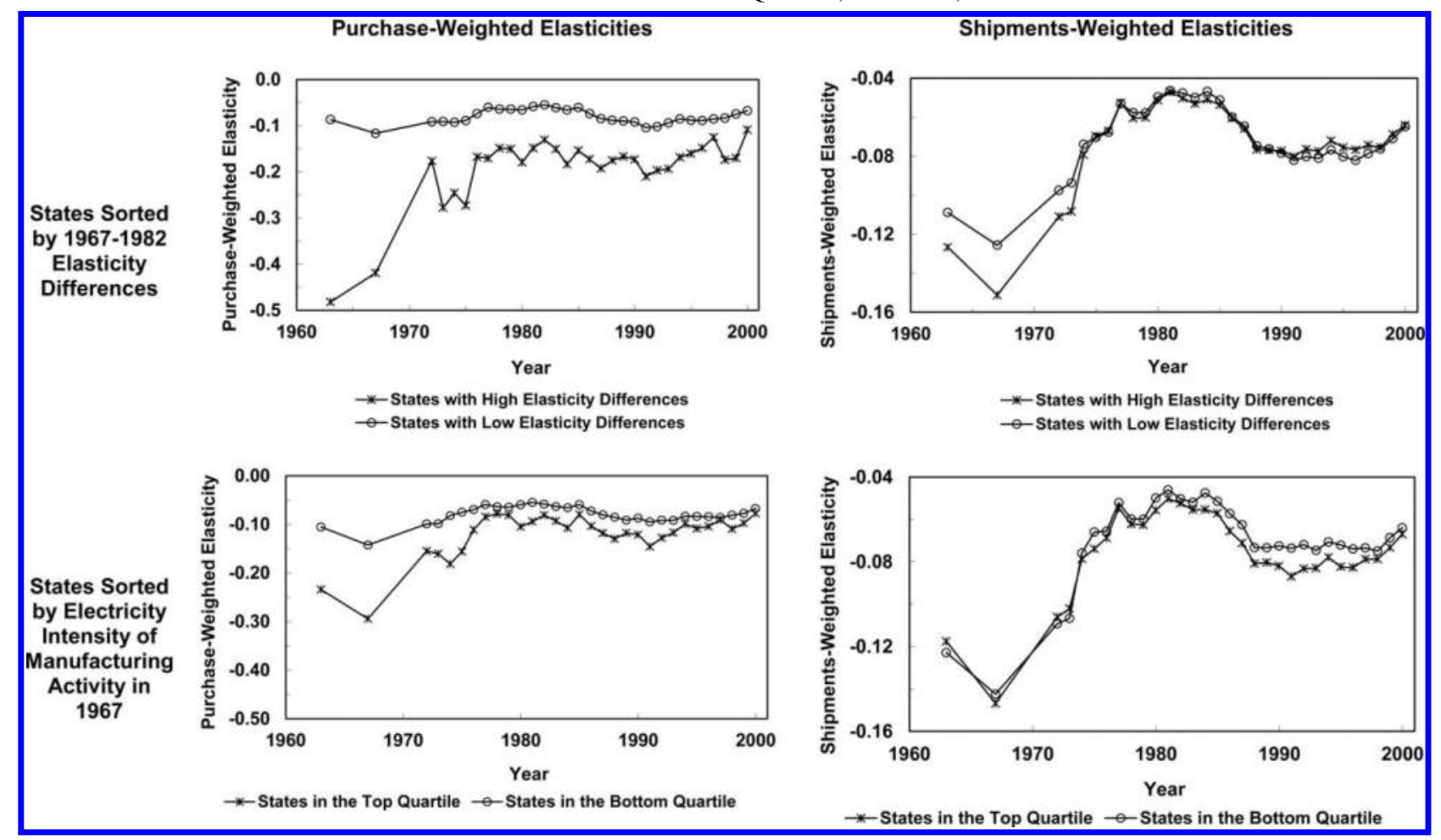

Electricity intensity measured by the shipments-weighted mean of industry-level cost shares in the state in 1967. Source: Authors' calculations on PQEM data.

Table 4.-Summary Statistics for Measures of Cost Drivers and Regulatory Factors

\begin{tabular}{|c|c|c|c|c|c|c|}
\hline \multirow[b]{2}{*}{ Description } & \multicolumn{3}{|c|}{ Purchase Weighted } & \multicolumn{3}{|c|}{ Shipments Weighted } \\
\hline & Mean & $\begin{array}{l}\text { Standard } \\
\text { Deviation }\end{array}$ & $\begin{array}{l}\text { Standard Deviation } \\
\text { Conditional on } \\
\text { Year Effects }\end{array}$ & Mean & $\begin{array}{l}\text { Standard } \\
\text { Deviation }\end{array}$ & $\begin{array}{l}\text { Standard Deviation } \\
\text { Conditional on } \\
\text { Year Effects }\end{array}$ \\
\hline Fossil fuel cost index & 1.027 & 0.185 & 0.128 & 1.012 & 0.171 & 0.122 \\
\hline Share of electricity from hydropower & 0.118 & 0.226 & 0.226 & 0.087 & 0.171 & 0.171 \\
\hline Share of electricity from nuclear & 0.155 & 0.160 & 0.149 & 0.187 & 0.157 & 0.150 \\
\hline Share of electricity from oil and natural gas & 0.189 & 0.255 & 0.246 & 0.202 & 0.236 & 0.228 \\
\hline Share of electricity from coal & 0.526 & 0.322 & 0.322 & 0.502 & 0.309 & 0.309 \\
\hline Share of electricity from other & 0.012 & 0.038 & 0.037 & 0.022 & 0.053 & 0.051 \\
\hline Elected public utility commission & 0.205 & 0.404 & 0.403 & 0.154 & 0.361 & 0.360 \\
\hline Implements fuel adjustment clauses & 0.618 & 0.357 & 0.298 & 0.671 & 0.322 & 0.293 \\
\hline Adopts proactive policy & 2.230 & 1.177 & 0.803 & 2.589 & 1.025 & 0.811 \\
\hline
\end{tabular}

Statistics are for observations at the state-year level, excluding Nebraska for 1963, 1967, and 1972-2000. Statistics are weighted by the ASM sample-weighted sum of purchases (shipments) in the state-year. The standard deviation conditional on year effects is computed after removing year fixed effects.

Source: Authors' calculations on data from the PQEM, State Energy Data 2008, and various National Association of Regulatory Utility Commissioners publications.

the convergence in the steepness of electricity price-quantity schedules documented in the top left panel of figure 7 is concentrated among states that have an electricity-intensive manufacturing sector. Interestingly, states with the most electricity-intensive industry structures offered the largest declines in prices with quantity in the era of low energy costs.

We now pursue a more systematic investigation of factors underlying the state-level differences in the elasticities and their changes over time. We focus on cost and regulatory factors and, in light of figure 7 , control for the electricity intensity of the state-level industry structure. For cost factors, we follow the lead of Joskow (2006) in identifying cost drivers of electricity prices. Our outcome variable is the elasticity of price with respect to purchase quantity (rather than price itself), but we still anticipate a role for cost drivers. One of our cost measures is the average fossil fuel price faced by utilities in the state and year. In addition, we use measures for the share of electricity generated by each type of fuel by state and year as indicators. For the latter, we include not only fossil fuels but also nuclear power and hydropower. Table 4 reports summary statistics of the cost driver measures and shows that there is much variation across states and years in these measures. The online appen- 
Figure 8.-Weighted Median and 10th and 90th Percentiles for State-Level Proactive Policy Adoption Index Values, 1963-2000

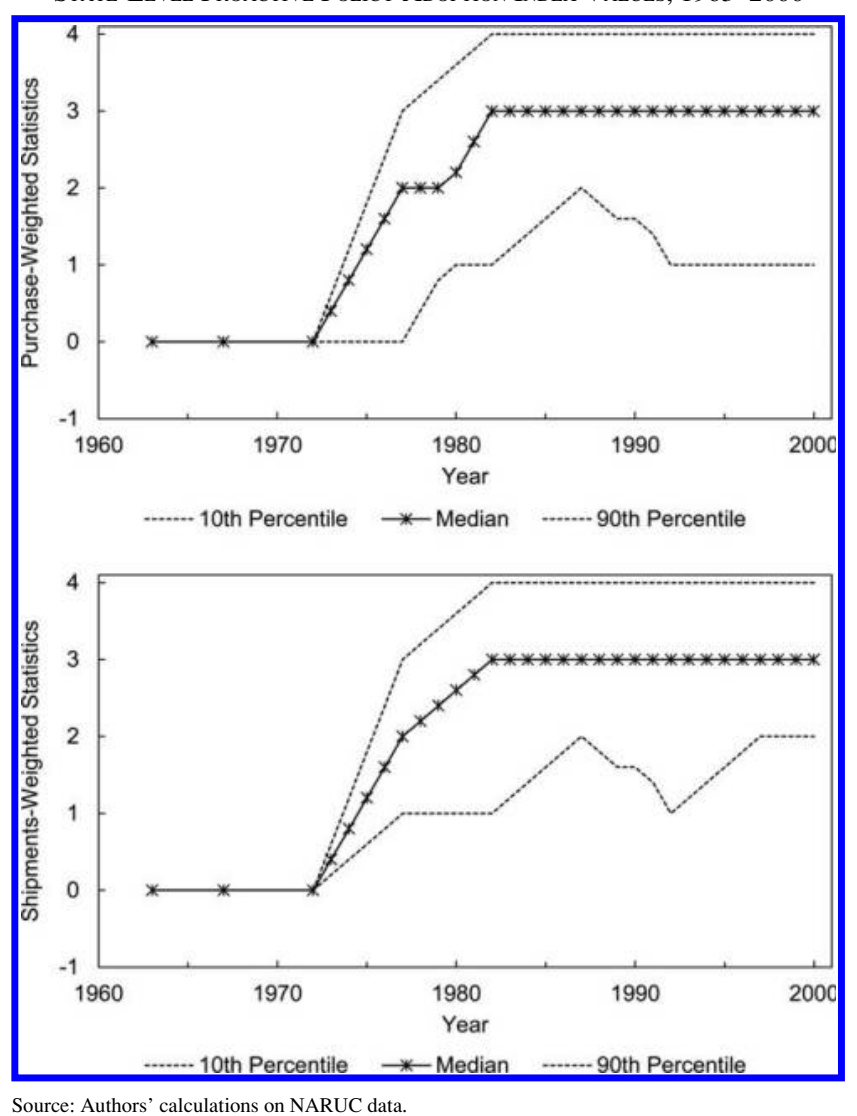

dix provides additional information about how the distribution of these measures changed over time across states.

For the measures of regulatory change and reform, we build on Joskow (1979a, 1979b). Joskow (1979a) describes the regulatory changes called for by PURPA as well as the conditions leading up to PURPA during the 1970s. He describes the key provisions in PURPA intended to promote efficient use of electricity. These include moving away from declining block rate structures (unless it could be clearly demonstrated that costs fell systematically with purchase quantity), use of time-of-day rates, seasonal rates, and interruptible power supply. Joskow (1979b) describes how states differed over the course of the 1970s in how aggressively they sought to change their rate structure on these dimensions. We exploit this variation in our analysis. In particular, we use the National Association of Regulatory Utility Commission (NARUC) surveys of utilities conducted annually from 1977 to 1996 . Joskow (1979b) takes advantage of these early and related survey efforts in 1977 to explore differences across states at that time. Since we seek consistent measures over time at the state level, we focus on NARUC survey questions that are consistent over time. Specifically, we use the survey questions on whether declining block rates have been approved for use for at least some class of customers, whether flat rates have been approved for use for some class of customers, whether sea- sonal rates have been approved and are in effect, and if interruptible power supply rates have been approved and are in effect. Joskow (1979a, 1979b) identifies these factors as being an important part of the regulatory reforms over this period.

We construct a simple cumulative index based on answers to these questions (details are in the online appendix). We code a value of 0 or 1 for the answer to each question, where 1 reflects a proactive rate structure policy-not using declining block rates, using flat rates, using seasonal rates, and using interruptible rates. The cumulative index is the simple sum of the coded values to these questions. For robustness purposes, we also considered a normalized cumulative index. We constructed the latter by first normalizing each of the components to have mean 0 and standard deviation equal to 1 and then constructed a normalized cumulative index by summing the normalized components. The correlation of the simple cumulative index and the normalized cumulative index is 0.98 , so we use just the simple index in what follows. We also construct measures of whether the state utility commission has fuel adjustment clauses and a measure of whether the state utility commission is elected or appointed. Details of the sources for these measures and their construction are provided in the online appendix.

There are large differences across states and across time for all of these indices, as is apparent from table 4. Figure 8 shows, for example, percentiles of the proactive policy index by year across states. There is a rapid rise in the median of this index over the 1970s, but the index increases much more for some states relative to others using the 90th and 10th percentiles. The online appendix describes how the distribution of the other regulatory and policy variables changed over time across states. The roughly coincident timing in the 1970s of the change in elasticities and the changes in policies, as well as the differences across states, suggest these patterns are potentially related. We now turn to investigating this hypothesis and, more generally, whether our indicators of the state-year variation in the regulatory and policy structure can account for the patterns in figures 5 and 7.

Table 5 reports results of OLS regressions relating the elasticity of price with respect to quantity at the state-year level to cost drivers and policy variables. As a control, we also include our index for the electricity intensity of the state's manufacturing sector. ${ }^{28}$ We estimate specifications on both a purchase- and shipments-weighted basis and with and without year effects. When we omit year effects, we

\footnotetext{
${ }^{28}$ Specifically, we include the deviation of this index at the state-byyear level from its annual mean value. We included this measure in deviation form since this also facilitated the consideration of specifications with interaction effects of this variable with the other right-hand-side variables. We found that while some individual interaction effects are statistically significant, the interaction terms added little or no explanatory power for the aggregate patterns we seek to explain. The online appendix contains results for the interaction specifications.
} 
Table 5.-Regression Results for State-Year Mean Elasticity Values

Dependent Variable: Weighted Mean Elasticity of Price with Respect to Purchase Quantity

\begin{tabular}{|c|c|c|c|c|c|c|}
\hline & \multicolumn{3}{|c|}{ Purchase-Weighted Elasticity } & \multicolumn{3}{|c|}{ Shipments-Weighted Elasticity } \\
\hline & (1a) & $(2 a)$ & (3a) & (1b) & (2b) & (3b) \\
\hline Intercept & $\begin{array}{c}-0.210 * \\
(0.012)\end{array}$ & $\begin{array}{c}-0.078 * \\
(0.009)\end{array}$ & $\begin{array}{c}-0.126^{*} \\
(0.020)\end{array}$ & $\begin{array}{c}-0.101 * \\
(0.003)\end{array}$ & $\begin{array}{c}-0.065^{*} \\
(0.001)\end{array}$ & $\begin{array}{r}-0.072 * \\
(0.002)\end{array}$ \\
\hline Fossil fuel cost index & $\begin{array}{c}0.019 \\
(0.010)\end{array}$ & & $\begin{array}{c}0.003 \\
(0.013)\end{array}$ & $\begin{array}{c}0.009 * \\
(0.002)\end{array}$ & & $\begin{array}{c}0.002 \\
(0.001)\end{array}$ \\
\hline Share of electricity from hydropower & $\begin{array}{c}0.022^{*} \\
(0.008)\end{array}$ & & $\begin{array}{c}0.010 \\
(0.008)\end{array}$ & $\begin{array}{c}0.007 * \\
(0.002)\end{array}$ & & $\begin{array}{c}0.004 * \\
(0.001)\end{array}$ \\
\hline Share of electricity from nuclear & $\begin{array}{c}0.163 * \\
(0.012)\end{array}$ & & $\begin{array}{c}0.171 * \\
(0.011)\end{array}$ & $\begin{array}{c}-0.002 \\
(0.002)\end{array}$ & & $\begin{array}{c}0.006^{*} \\
(0.001)\end{array}$ \\
\hline Share of electricity from oil and natural gas & $\begin{array}{c}0.093 * \\
(0.007)\end{array}$ & & $\begin{array}{c}0.091 * \\
(0.007)\end{array}$ & $\begin{array}{c}0.008 * \\
(0.002)\end{array}$ & & $\begin{array}{c}0.005^{*} \\
(0.001)\end{array}$ \\
\hline Elected public utility commission & $\begin{array}{c}0.016^{*} \\
(0.005)\end{array}$ & & $\begin{array}{c}0.012 * \\
(0.005)\end{array}$ & $\begin{array}{c}0.001 \\
(0.001)\end{array}$ & & $\begin{array}{r}-0.001 * \\
(0.000)\end{array}$ \\
\hline Implements fuel adjustment clauses & $\begin{array}{c}0.005 \\
(0.005)\end{array}$ & & $\begin{array}{r}-0.026^{*} \\
(0.006)\end{array}$ & $\begin{array}{c}0.013 * \\
(0.001)\end{array}$ & & $\begin{array}{c}0.001 * \\
(0.000)\end{array}$ \\
\hline Adopts proactive policy & $\begin{array}{c}0.013^{*} \\
(0.002)\end{array}$ & & $\begin{array}{c}0.004 \\
(0.002)\end{array}$ & $\begin{array}{c}0.004 * \\
(0.000)\end{array}$ & & $\begin{array}{c}0.001 * \\
(0.000)\end{array}$ \\
\hline Industry-based energy intensity index & $\begin{array}{c}-0.016^{*} \\
(0.004)\end{array}$ & & $\begin{array}{c}-0.020 * \\
(0.004)\end{array}$ & $\begin{array}{c}-0.002 \\
(0.001)\end{array}$ & & $\begin{array}{r}-0.004 * \\
(0.000)\end{array}$ \\
\hline Year fixed effects & No & Yes & Yes & No & Yes & Yes \\
\hline$N$ & 1,550 & 1,550 & 1,550 & 1,550 & 1,550 & 1,550 \\
\hline Adjusted $R^{2}$ & 0.247 & 0.126 & 0.323 & 0.189 & 0.865 & 0.897 \\
\hline
\end{tabular}

Regressions are on state-year level data by weighted least squares. Weights are the ASM sample-weighted state-year sum of purchases or shipments, as indicated. Years are 1963, 1967, and 1972-2000. The dependent variable is the purchase(shipments)-weighted mean of the estimated establishment-level elasticity for all establishments in the state-year. We estimated these elasticities using the same specification as in the lower panel of figure 4 (that is, inclusive of utility fixed effects). We drop Nebraska from all models due to missing values for many of the regulatory variables. ${ }^{*} p<0.05$.

Source: Authors' calculations on data from the PQEM, State Energy Data 2008, and various National Association of Regulatory Utility Commissioners publications.

are permitting common patterns in the cost drivers and policy variables to identify the effects of interest. When we include year effects, we are permitting only state-specific movements in the cost drivers and policy variables to identify the effects of interest. The middle column of the panel shows how much the year effects account for by themselves.

Column 1a shows the results without year effects. In this specification, we find that cost drivers are important determinants of the variation in elasticities across states and years. The fossil fuel index has a positive and marginally significant effect, indicating that states with high fossil fuel costs tend to have flatter price-quantity schedules. In turn, states with high shares of electricity from nuclear and oil and natural gas also have flatter price-quantity schedules. Turning to the regulatory and policy differences across states and years, we find that states with an elected commission that has adopted a proactive policy have flatter pricequantity schedules. To get a sense of the magnitudes of the implied effects, a 1 standard deviation change in the proactive policy index (using the purchase-weighted distribution) is associated with a 0.015 increase in the elasticity (the elasticity becomes less negative). We also find that states with more energy-intensive industries have more negative (steeper price-quantity schedules) elasticities, consistent with the patterns in figure 7.

Column 3a shows the results when we control for year effects. Inclusion of these effects captures any common movement in the cost drivers and policy variables, so that identification is based on only differences in these variables across states over time. In this specification, the impact of the elected utility indicator becomes smaller but is still significant, and the proactive policy indicator also becomes smaller and is only marginally significant. Here, a 1 standard deviation change in the proactive policy index using the purchase-weighted distribution is associated with a 0.005 increase in the elasticity.

Turning to the shipments-weighted results, we find that year effects account for virtually all of the state-by-year variation in this distribution. This finding is consistent with figure 7, which shows relatively little variation across states in their changes in elasticities. As such, the effects estimated in the shipments-weighted panel are all smaller since there is much less variation to account for in the shipmentsweighted distribution. Interestingly, we still find a positive (albeit small) and statistically significant effect of the proactive policy index even when we control for year effects.

Figure 9 summarizes the contribution of the explanatory variables to the aggregate patterns we observe in figure 5 . To construct figure 9, we use the mean predicted values by year of the various model estimates from table 5. The top panel shows results using the model estimates from the purchase-weighted results. The mean purchase-weighted elasticity increased by $14.8 \mathrm{log}$ points from 1967 to 1982 . The predicted change from all of the right-hand-side variables using model 1a (Policy) is $5.2 \mathrm{log}$ points over this same period of time. The predicted change from the regulatory and policy variables using model $1 \mathrm{a}$ is $3.6 \mathrm{log}$ points. These calculations, taken at face value, imply that the cost drivers, plus the regulatory and policy variables, account for about $35 \%$ of the flattening of the price-quantity relationship from 
Figure 9.-Actual and Predicted Weighted Mean Elasticity of Price with Respect to Purchase Quantity Values, 1963-2000

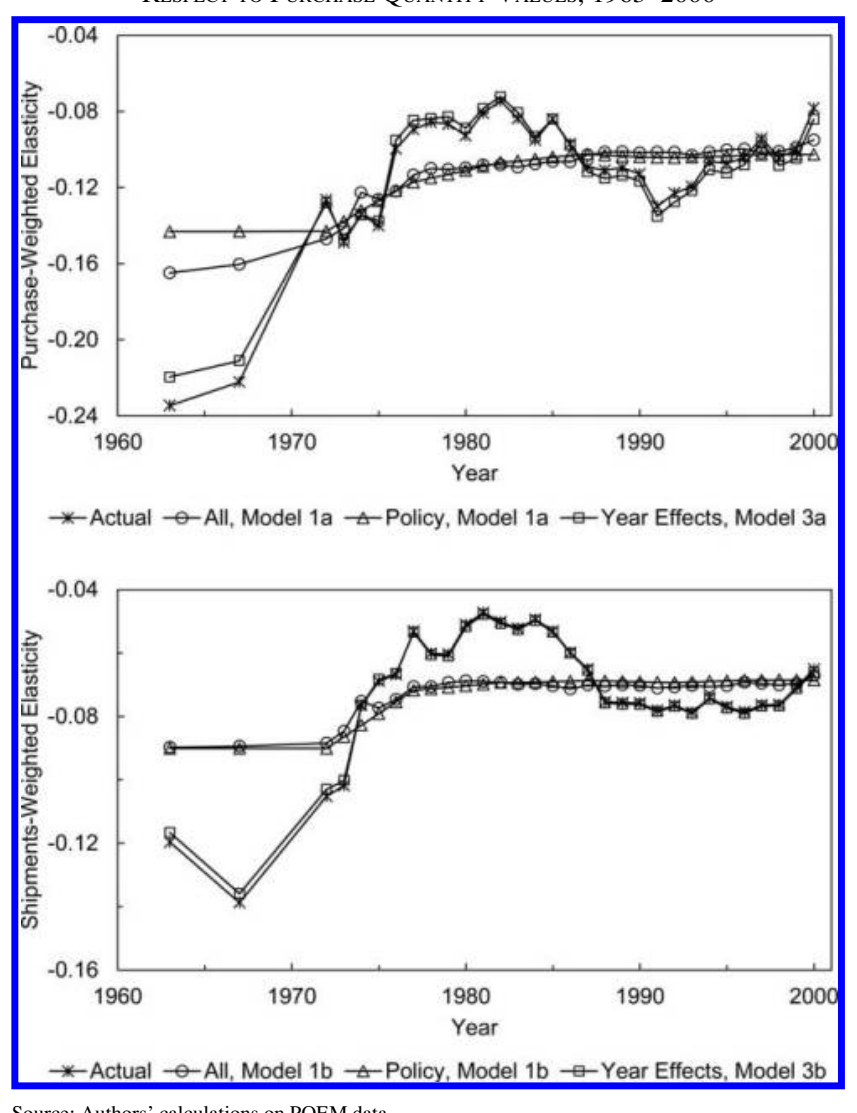

Source: Authors' calculations on PQEM data.

1967 to 1982 and that the regulatory and policy variables account for $25 \%$ by themselves.

The findings from model 1a for the purchase-weighted results suggest that a substantial fraction of the variation across states reflects cost drivers and regulatory factors. However, caution is warranted since model 1a does not include year fixed effects. Inclusion of the latter captures any unaccounted-for common factor affecting the elasticity across states. Using the estimates from model 3 a shows that the year effects alone account for about $13.9 \log$ points over this period. The difference between the actual and residual year effects yields the contribution of the right-hand-side variables in model $3 \mathrm{a}$. This calculation implies that the other right-hand-side variables in model $3 \mathrm{a}$ (cost drivers plus regulatory and policy variables) account for only about $6 \%$ of the change over this period. The contrast between models 1a and 3a highlights the challenge of identifying the effects of cost drivers and regulatory factors variables given the potential presence of unobserved common factors.

Turning to the shipments-weighted panel of figure 9, the cost drivers and regulatory and policy variables in models $1 \mathrm{~b}$ and $3 \mathrm{~b}$ account for less of the variation in the mean actual change in elasticity. The change over the 1967 to 1982 period is $8.9 \log$ points. Model $1 \mathrm{~b}$ (All) accounts for $2.0 \mathrm{log}$ points and model $1 \mathrm{~b}$ (Policy) for $2.1 \mathrm{log}$ points. In model $3 \mathrm{~b}$, year effects alone account for $8.5 \log$ points. The implication is that in model $3 \mathrm{~b}$, cost drivers plus regulatory and policy variables account for very little of the mean change in the elasticity. This is not surprising given what we had already learned from figure 7: there is not much variation across states in the shipments-weighted changes in elasticities.

We briefly summarize the implications of figure 9 as follows. ${ }^{29}$ First, on a purchase-weighted basis, there is considerable variation across states in the flattening of the pricequantity schedules. Second, using the estimates without year effects, cost drivers plus regulatory factors account for $35 \%$ of this flattening, with regulatory variables accounting for $25 \%$. Cost and regulatory factors account for considerably less of the variation in the specification with year effects. Third, on a shipments-weighted basis, there is not much variation across states in the flattening of the pricequantity schedules and, hence, not much of a role for statespecific variation in the cost and regulatory variables.

\section{Conclusion}

This study documents tremendous dispersion across manufacturing plants in the price paid per $\mathrm{kWh}$ of electricity. Spatial price differentials and price gaps between larger and smaller purchasers account for all but a small fraction of the overall dispersion in prices. Price gaps between larger and smaller purchasers are enormous, even when controlling for plant location or electric utility.

The price structure exhibits notable changes over time: The cross-sectional price distribution became much more compressed from the 1960s to the late 1970s due to shrinking price gaps between larger and smaller purchasers. Spatial price differentials declined markedly until the late 1980s for large purchasers but rose over time for small purchasers. The expansion of wholesale power markets in the 1990s had no apparent effect on spatial price dispersion at the retail level for manufacturing plants, which strikes us as something of a puzzle.

We show that states differ significantly in the extent of the flattening of the price-quantity schedules between the late 1960s and early 1980s on a purchase-weighted basis but not much on a shipments-weighted basis. For the purchase-weighted variation, states with the most electricityintensive manufacturing sector had the steepest price-quantity relationships in the 1960 s and exhibited the greatest flattening. We provide evidence that states differed substantially in the extent of regulatory reform over this period and that they faced different cost pressures due to different fuel mixes in power generation. We find evidence that more proactive states in terms of regulatory reform and states

\footnotetext{
${ }^{29}$ To address the possibility that public power authority customers behave differently from other customers and drive our purchase-weighted results, we recreated several of our exercises excluding public power authority customers. See the online appendix for results. Although there are some differences, the basic story told in figure 9 holds when we exclude public power authority customers.
} 
with elected public utility commissions exhibited a greater flattening of price-quantity schedules. However, there are challenges to identification in this regard because many states adopted regulatory reforms at about the same time.

\section{REFERENCES}

Besanko, David, Julia D'Souza, and S. Ramu Thiagarajan, "The Effect of Wholesale Market Deregulation on Shareholder Wealth in the Electric Power Industry," Journal of Law and Economics 44 (2001), 65-88.

Besley, Timothy, and Coate, Stephen, "Elected versus Appointed Regulators: Theory and Evidence," Journal of the European Economic Association 1 (2003), 1176-1206.

Borenstein, Severin, "The Trouble with Electricity Markets: Understanding California's Restructuring Disaster," Journal of Economic Perspectives 16 (2002), 191-211.

Caywood, Russell E., Electric Utility Rate Economics (New York: McGraw-Hill, 1956).

_ Electric Utility Rate Economics (New York: McGraw-Hill, 1972).

Cowern, Edward H., "Power and Energy: Factors that Determine Industrial Electric Bills," Cowern Papers presented by Motors and Drives, LLC. (2001). www.motorsanddrives.com/.

Cudahy, Richard D., and J. Robert Malko, "Electric Peak-Load Pricing: Madison Gas and Beyond," Wisconsin Law Review 47 (1976), 47-78.

Davis, Steven J., Cheryl Grim, John Haltiwanger, and Mary Streitwieser, "Prices and Quantities of Electricity in the U.S. Manufacturing Sector: A Plant-Level Database and Public-Release Statistics, 1963-2000" (2007), www.econ.umd.edu/ haltiwan/pqem.pdf.

Davis, Steven J., and John Haltiwanger, "Wage Dispersion between and within U.S. Manufacturing Plants, 1963-1986," in Martin Neil Baily and Clifford Winston, eds., Brookings Papers on Economic Activity: Microeconomics (Washington, DC: Brookings Institution, 1991).

Environmental Law Reporter, "Electric Utility Rate Design: The Move toward Peak-Load Pricing," Environmental Law Reporter 5 (1975), 10084.

Foster, Lucia, John Haltiwanger, and C. J. Krizan, “Aggregate Productivity Growth: Lessons from Microeconomic Evidence," in Edward Dean, Michael Harper, and Charles Hulten, eds., New Directions in Productivity Analysis (Chicago: University of Chicago Press, 2001).

Gordon, Richard L., Reforming the Regulation of Electric Utilities (Lexington, MA: Lexington Books, 1982).

Hirsh, Richard F., Technology and Transformation in the American Electric Utility Industry (Cambridge: Cambridge University Press, 1989).
Power Loss: The Origins of Deregulation and Restructuring in the American Electric Utility System (Cambridge, MA: MIT Press, 1999).

Joskow, Paul L., "Inflation and Environmental Concern: Structural Change in the Process of Public Utility Price Regulation," Journal of Law and Economics 17 (1974), 291-327.

"Public Utility Regulatory Policies Act of 1978: Electric Utility Rate Reform," Natural Resources Journal 19 (1979a), 787-809.

"Electric Utility Rate Structures in the United States: Some Recent Developments," in W. Sichel, Ed., Public Utility Ratemaking in an Energy Conscious Environment (Boulder, CO: Westview Press, 1979b).

"Regulatory Failure, Regulatory Reform, and Structural Change in the Electric Power Industry," in Martin Neil Baily and Clifford Winston, eds., Brookings Papers on Economic Activity: Microeconomics (Washington, DC: Brookings Institution, 1989).

"Deregulation and Regulatory Reform in the U.S. Electric Power Sector," in S. Peltzman and Clifford Winston, eds., Deregulation of Network Industries: The Next Steps (Washington, DC: Brookings Institution Press, 2000).

"The Difficult Transition to Competitive Electricity Markets in the United States," in J. Griffin and S. Puller, eds., Electricity Deregulation: Choices and Challenges (Chicago: University of Chicago Press, 2005).

"Markets for Power in the United States: An Interim Assessment," Energy Journal 27 (2006), 1-36.

Joskow, Paul L., and Richard Schmalensee, "Incentive Regulation for Electric Utilities," Yale Journal on Regulation 4 (1986), 1-49.

U.S. Energy Information Administration, "Inventory of Nonutility Electric Power Plants in the United States 1999," U.S. Department of Energy/Energy Information Administration document DOE/EIA0095(99)/2 (2000a).

"The Changing Structure of the Electric Power Industry 2000: An Update," U.S. Department of Energy/Energy Information Administration document DOE/EIA-0562(00) (2000b).

“Annual Energy Review 2002,” U.S. Department of Energy/ Energy Information Administration Document DOE/EIA-0384(2002) (2003a).

"Electric Power Annual 2002," U.S. Department of Energy/ Energy Information Administration document DOE/EIA-0348(2002) (2003b).

Van Biesebroeck, Johannes, "Robustness of Productivity Estimates," NBER working paper 10303 (2004).

White, Matthew W., "Power Struggles: Explaining Deregulatory Reform in Electricity Markets," in Martin Neil Baily, Peter C. Reiss, and Clifford Winston, eds., Brookings Papers on Economic Activity: Microeconomics (Washington, DC: Brookings Institution, 1996).

Wilson, Robert B., Nonlinear Pricing (New York: Oxford University Press, 1993). 